Portland State University

PDXScholar

Dissertations and Theses

Dissertations and Theses

1978

\title{
A readership study of Oregon wildlife magazine
}

Deborah C. Sullivan

Portland State University

Follow this and additional works at: https://pdxscholar.library.pdx.edu/open_access_etds

Part of the Mass Communication Commons, and the Publishing Commons Let us know how access to this document benefits you.

Recommended Citation

Sullivan, Deborah C., "A readership study of Oregon wildlife magazine" (1978). Dissertations and Theses. Paper 2840.

https://doi.org/10.15760/etd.2834

This Thesis is brought to you for free and open access. It has been accepted for inclusion in Dissertations and Theses by an authorized administrator of PDXScholar. Please contact us if we can make this document more accessible: pdxscholar@pdx.edu. 
AN ABSTRACT OF THE THESIS OF Deborah C. Sullivan for the Master of Science in Speech Communication presented May 10, 1978.

Title: A Readership Study of Oregon Wildlife Magazine. APPROVED BY MEMBERS OF THE THESIS COMMITTEE:
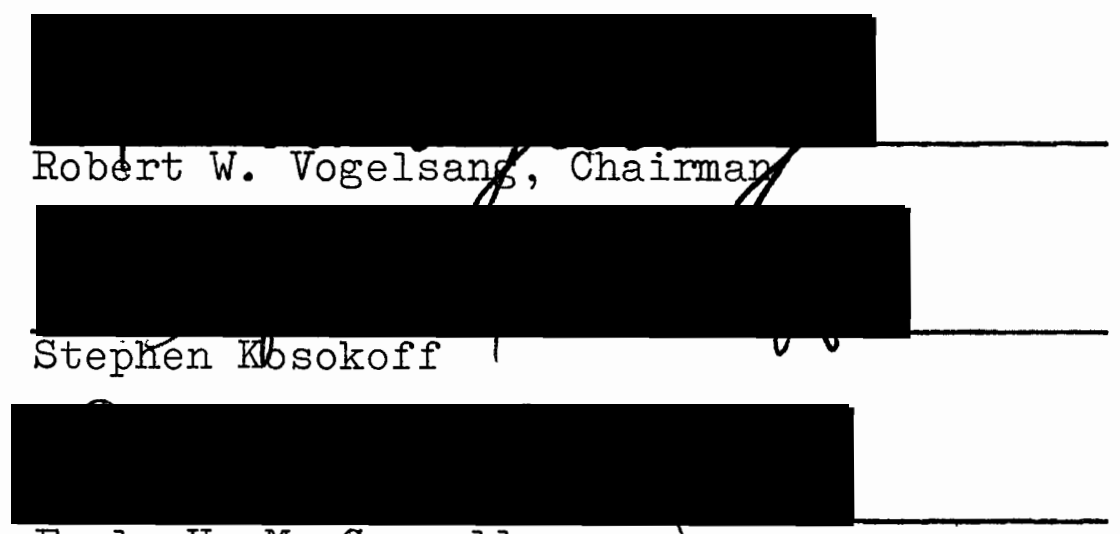

Earle H. MacCannell

The purpose of this study was to determine the extent and frequency of readership of the Oregon Wildlife magazine and this relationship to Klapper's reinforcing hypothesis.

The basic question posed was: What population of individuals in Oregon read which types of fish and wildlife articles in the Oregon Wildlife magazine, and how do these respondents assess the readability and accuracy of the magazine?

Oregon Wildlife magazine is a free, twelve-page, monthly publication, published by the Oregon State 
Department of Fish and Wildife. The magazine deals with various fish and wildlife information which would appeal to the licensed hunter and angler, as well as others in the state who are interested in the field. Oregon Wildlife realizes a circulation of sixty-two thousand, ten thousand of whom are licensed dealers who distribute the bulletin over the counter. Ninety-five percent of those who receive the magazine on a subscriber basis live in the state of Oregon.

A sample of names of Oregon Wildlife subscribers was drawn from the Department of Wildlife's computerized IBM cards. One out of every one hundred names in the computer was drawn and a questionnaire was sent to them. Fifty-two percent (273) of the questionnaires were completed and returned.

The majority of respondents were males, between the ages of 60-69 years, living in mural areas and either retired or working in labor and trade fields. Almost all respondents first heard about Oregon Wildlife from a friend. The majority of respondents reported that they read every issue and always or nearly always read the general types of articles appearing in the magazine. All or part of the specific articles in April 1977 and the May 1977 issues were read. Most respondents appraise the accuracy of Oregon Wildlife portraying what is going on in the field as "very accurately" or "fairly accurately" and 
appraise the readability, or style of writing as "about right." Approximately one-half of respondents subscribe to other wildife magazines and the majority of respondents have purchased a hunting or angling license within the past five years.

The data were also analyzed according to the following hypothesis, based on Joseph Klapper's five generalizations. Hypothesis: There will be no significant difference between reinforcement of how often general types of articles are read as compared to the sentiments on readability and accuracy of the magazine.

The null hypothesis was rejected on the basis that the majority of respondents appraise the readability as "about right," the accuracy as "very accurately" or "fairly accurately," and most often "always" or "nearly always" read the general types of articles appearing in the magazine. Thus the reinforcement hypothesis as espoused by Klapper was supported by the findings of the study. 
A READERSHIP STUDY OF OREGON WILDLIFE MAGAZINE

by

DEBORAH C. SULIIVAN

A thesis submitted in partial fulfillment of the requirements for the degree of

\author{
MASTER OF SCIENCE \\ in \\ SPEECH COMMUNICATION
}

Portland State University

1978 
TO THE OFFICE OF GRADUATE STUDIES AND RESEARCH:

The members of the Committee approve the thesis of Deborah C. Sullivan presented May 10, 1978.

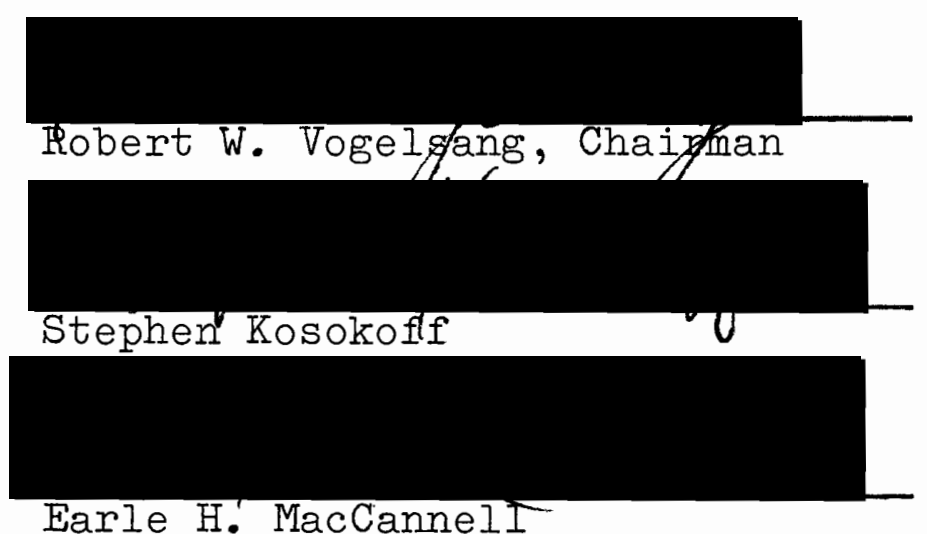

APPROVED :

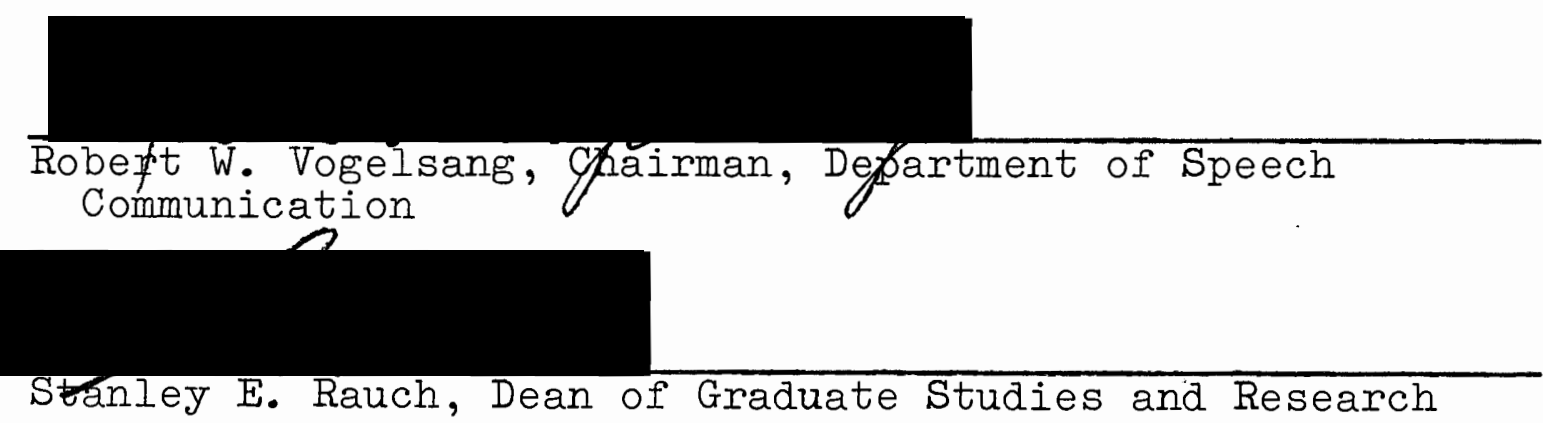




\section{ACKNOWIEDGMENTS}

At this time I would like to express my deep appreciation to those who encouraged and guided me throughout this study.

Foremost, my thanks is extended to my chairman, Dr. Robert Vogelsang who inspired and kept me aware of my responsibilities with careful and thoughtful consideration. Dr. Earle MacCannell's patience and insightful knowledge of the subject matter provided me with the incentive for extended research. Dr. Steve Kosokoff aided in clarifying concepts as well as posing alternative viewpoints, and Dr. Ted Grove went far out of his way to help with form and statistics.

The Oregon Wildlife Commission's helpful cooperation and assistance with facilities is greatly appreciated. Also the many subscribers who took the time and effort to complete and return the questionnaires. I am very grateful to Ron Shay, editor of Oregon Wildlife, for introducing me to the subject matter. His assistance in clarifying information without bias direction was most helpful.

I owe more than a thank you to my friends Ken Gerger and Jeff Sweeney, who gave their time to help tabulate and key-punch. 
A special thanks to Margaret Harmash and Tom Battles for their patient work on the graphic design of the figures, and to Barbara Vogelsang for her kindness and professional ability which carried me through the hectic days with confidence.

Lastly and most important, my gratitude is extended to Danny O'Shea and my mother Anne Sullivan. Their thoughtful listening, patience, and love will always be warmly remembered. 
TABLE OF CONTENTS

PAGE

ACKNOWLEDGMENTS

LIST OF TABLES

vii

LIST OF FIGURES

CHAPTER

I INTRODUCTION • • • • • • • • • • • •

II REVIEW OF THE IITERATURE . • . . • . . 3

III PROBLEMS AND PROCEDURES . • • • • • • 13

Statement of the Problem . . . . . 13

Hypothesis to be Tested . . . . . 13

Definition of Terms . . . . . . 14

Assumptions . . . . . . . . 15

Procedures ........... 15

IV RESUITS . . . . . . . . . . . 22

General Results. . . . . . . 22

The Respondents . . . . . . . . 33

Sources of Information . . . . . 36

Readership of Issue . . . . . . 37

Accuracy and Readability . . . . . 39

Subscription to Other Magazines and

Purchase of Hunting or Angling

License . • . • . • • • . • 
CHAPTER

PAGE

Independent Variables of Respondents and General Articles.... . . 42

V SUIMTARY AND CONCLUSION . • • • • • . 63

Summary ........... . . 63

Conclusions .......... 66

Suggestions for Further Research . . 67

BIBLIOGRAPHY

APPEND IX

A The Cover Letter and Questionnaire . . .

$B$ Comparison of Independent Variables and

Responses to General Types of

Articles Read (Age, Occupation,

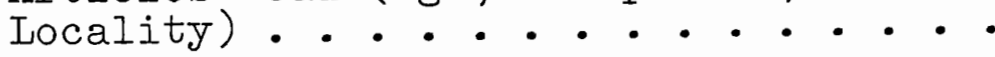


LIST OF TABLES

TABIE

PAGE

I Reasons for Non-Delivery of Questionnaire • 20

II General Articles and How Often Read . . •

III Specific Articles from April, 1977 Issue and How Often Read . . . . . . .

IV Specific Articles from May, 1977 Issue and How Often Read . . . . . . •

$\mathrm{V}$ Ages of Respondents . . . . . . . . . 34

VI Occupational Divisions . . . . . . . . 35

VII Area of Residence . . . . . . . . . . 36

VIII Source of Information Comparison . . . • 37

IX Readership of Sample's Issue Other than

Respondent •. • • . • • • . • • • 38

X Number of Years Respondent has been Reading

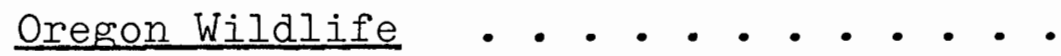

XI Source Exposure and General Articles . . . 45

XII General Articles and Source Exposure . . • 49

XIII Accuracy Appraisal and General Articles . • 52

XIV General Articles and Accuracy Appraisal . • 55

XV Readability Appraisal and General

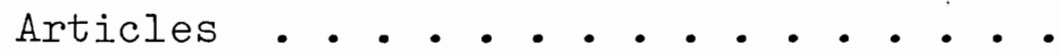


XVI General Articles and Readability

$$
\text { Appraisal . . . . . . . . . . } 60
$$

XVII Comparison of Age and Responses to General

$$
\text { Types of Articles Read - • • • : } \quad 8 \text { : }
$$

XVIII Comparison of Occupations and Responses to

$$
\text { General Types of Articles Read . . . • } 81
$$

XIX Comparison of Locality and Responses to

$$
\text { General Types of Articles Read . . . . } 82
$$


IIST OF FIGURES

FIGURE

PAGE

1 Histogram Comparing Source Exposure and

General Types of Articles Read . . . . 46

2 Histogram Comparing General Types of

Articles Read and Source Exposure . . 50

3 Histogram Comparing Accuracy Appraisal

and General Types of Articles Read . . 53

4 Histogram Comparing General Types of

Articles Read and Accuracy Appraisal • • 56

5 Histogram Comparing Readability Appraisal

and General Types of Articles Read . . . 59

6 Histogram Comparing General Types of

Articles Read and Readability

Appraisal . . . . . . . . . . . il 
CHAPTER I

INTRODUCTION

This study was performed in conjunction with the Oregon Department of Fish and Wildlife. The purpose of this study was to determine extent and frequency of readership of the Oregon Wildlife magazine.

The role of mass media as well as the public's relationship with the media are both examined. Through examination of this interaction of media and audience, more clear evaluations may be perceived of the mass communication process.

This study was especially concerned with reader attitudes toward the accuracy of the magazine in relating what goes on in the field, and readability or style of writing in the magazine.

Joseph Klapper's reinforcement theory on the effects of mass communication were applied to the findings. ${ }^{1}$

It is assumed that the results of this study will aid communication between the public and informational programs. 
Chapter 1--Notes

${ }^{I}$ Joseph T. Klapper, The Effects of Mass Communication (Glencoe, Illinois: The Free Press, 1960), p. 8. 


\section{CHAPTER II}

\section{REVIEW OF THE IITERATURE}

This chapter will review the literature that addresses itself to the impact of media with relation to the audience members. There exist numerous studies examining the influence of a single medium at a given time on a particular audience. However, few readership studies in the field of fish and wildlife have been performed to obtain feedback and determine the impact of the magazine medium on the audience.

Based on findings of wildlife information sources, Shay observed that "the magazine still is maintained as the mainstay of the state information and education budgets." ${ }^{1}$

Further, according to Shay's thesis, Douglas Gilbert, a specialist in the field of natural resources public relations, points out:

The conservation magazine is the most popular method of communications used by a state conservation department. (1962 survey) Approximately twenty percent of the information and education budget is spent to make a regularly scheduled, departmental publication available. Both radio and television were regularly scheduled efforts but were far behind written, field and personal methods of contact in popularity.

It is suggested therefore that attention be given to this realm in consideration of the information. Gilbert. 
further explains, ". . managers of our natural resources must make every effort to keep knowledge of their publics at the same level or at a higher level as knowledge of natural resource management." 3

In researching effects of mass communication, it is necessary to examine what role mass media plays in communication theory. In the past, most studies of mass communication have been evaluated from either the media source, the audience, or both. In "Mass Communication" by MacCannell, it is suggested that mass communication was either ignored by general communication theory, or that mass communication was considered to be the same process as communication in general. MacCannell suggests that to understand the interpretations of the effects of mass communication, the assumptions should be reexamined, and clarified by examining mass communication in terms of communication rather than media or audience. ${ }^{4}$

Mass communication then is similar to the dynamic communication process, with exception of the feedback process. In the mass communication process, feedback is either nonexistent or delayed. O'Hara explains, "consider the circumstances in which the mass communicator must send his message. Not only is he dealing with a heterogeneous throng of receivers, he has no direct contact with them. "5

Merrill and Iowenstein further elaborate on delayed feedback in Media, Messages, and Men: "Although delayed 
feedback occurs in various communication situations, it most often is thought of having to do with mass communication." 6

Based on this theory of mass communication, the effects of mass communication tend to take on alternative perspectives. In order to address the effects of mass communication, it is necessary to examine the material directed at the effects of mass media.

In The Effects of Mass Communication, Klapper reports his examination of past studies which were performed in evaluation of media effects. Based on his findings, Klapper proposed five generalizations which apply to his phenomenistic approach on media effects. Klapper's generalizations agree with and elaborate on, Lazarsfeld's earlier findings of media reinforcement. ${ }^{7}$ The five generalizations include:

1. Mass communication ordinarily does not serve as a necessary and suffieient cause of audience effects, but rather functions among and through a nexus of mediating factors and influences.

2. These mediating factors are such that they typically render mass communication a contributory agent, but not the sole cause, in a process of reinforcing the existing conditions.

3. On such occasions as mass communication does function in the service of change, one of two conditions is likely to exist. Either: a. the mediating factors will be found to be inoperative and the effect of the media will be found to be direct; or $\mathrm{b}$. the mediating factors, which normaliy favor reinforcement, will be found to be themselves impelling toward change.

4. There are certain residual situations in which mass communication seems to produce direct 
effects, or directly and of itself to serve certain psycho-physical functions.

5. The efficacy of mass communication, either as a contributory agent or as an agent of direct effect, is affected by various aspects of the media and communications themselves or of the communication situation. 8

In summarizing Klapper's generalization, MacCannell explains that content which is in agreement with preexisting beliefs is remembered longer and more accurately than content that is not in agreement. MacCannell further points out, that of Klapper's generalizations:

His implications that the unmediated effect of mass communication would be direct is not, however, a necessary conclusion from the data. Analysis of the symbolic interaction model of the communication process leads to the conclusion that the unmediated effects of mass communication would also be reinforcing rather than direct.9

The alternative view to the reinforcing effect of media is the hypodermic effect. Those who support the hypodermic effect believe that media has a direct effect on the audience. Klapper's mediating factors of predispositions (selective exposure, selective perception, selective retention) of the audience is not taken into consideration, as well as the mediating factors of groups and group norms, interpersonal dissemination of the content of communication, opinion leadership, and the nature of mass media itself.

MacCannell further explains that:

Those who believe in the hypodermic effect tend to be greatly concerned, even alarmed by their perception of the uses and misuses of the media. The 
three major concerns of those people are violence in the form of crime, war or brutality; sex in the form of pornography; and mind control of the masses by the few who control the media. On the other hand, those who accept the reinforcement effect hypothesis are much less concerned about those problems.10

In further addressing the effects of mass communication, several researchers suggest specific examination of audience behavior and reaction.

In examining how communication serves as a link between individuals and their environments, Dexter and White explain of Davison's on the Effects of Communication, that: "This suggests to him [Davison] that the effects of mass communications should be viewed in terms of the role they play in enabling people: to bring about more satisfying relationships between themselves and their environments." 11

Dexter and White further expound:

In a more detailed manner than either Wright or Fearing, Davison examines the role of attitudes as guides to action. By understanding the habits, stereotypes, attitudes, maxims, generalizations, and facts that human beings accumulate in the course of their experience we can begin to analyze why people have opinions.12

In examining effects of mass communication and the issue of audience members, it was found that although certain groups do have preferences in their use of the media, individuals also vary on various factors of dependence on the media. 
Theodore Peterson further explains this phenomenon:

- . to think of the audience of magazines as an entity distinct from the audiences of the other media is as misleading as to think of all members of the magazine audience as cut from the same pattern. Individuals varied tremendously in how many magazines they read (if indeed they read any at ali), in the amount of time they spent with them as compared with the other media, and in the uses they made of them.13

Resulting from such audience studies was Lazarsfeld and Kendall's "all or none" tendency, which considered persons above average in exposure to one media are above average in exposure to all media. ${ }^{14}$ Although amount of exposure may remain constant, individuals tend to choose different media sources for various information functions.

The American Institute for Political Communication suggests that:

The news magazine and the radio represent media in the sense that people are substantially less dependent upon them as primary news sources than they are on television and the daily paper. However, they remain very important media in that substantial segments of the public do listen to the radio and do read news magazines with a high degree of regularity. Furthermore, the radio and the news magazine perform functions and meet needs which the primary media do not. 15

Klapper ascertains that "certain characteristics of each medium are believed by various social scientists to provide that medium with unique capabilities as a persuasive instrument." $1 \epsilon$

In evaluating specifically the print media, Klapper further suggests that the print media allows the reader to control the occasion, the pace, the direction of his 
exposure, and permits him easy reexposure. "More easily than other media, print allows a topic to be developed to whatever length and with whatever complexity seems desirable."17

It is suggested by laboratory experiments, mainly before the 1930's that print media produces higher retention of complex factual material, although this does not apply to simple material. Print media is especially applicable to specialized audiences. Klapper also explains that print media is associated with culture and may carry comparatively higher prestige than do other media. Furthermore, Klapper suggests that:

- . print is believed by some observers to demand a more active creative participation on the part of the reader, than is demanded by other media, because the communication is less "structured"; it does not confront the reader with a visible or audible speaker, as do film, radio, and TV, and therefore permits him greater freedom to assign or imagine nuances, interpretations, and the like.18

The reader of print media is less personally involved, in that he is not personally addressed, yet the reader is more personally involved with the print media in the sense that in the absence of a speaker, the reader is forced to creatively participate. Hypotheses vary as to whether this creative participation (if it exists) is advantageous or hindering to persuasion.

Marshall Mcluhan's theory on the personal involvement with print media varies from Klapper's. McLuhan presents print media as "hot" and as following a linear 
path of logic, filled with data, which requires attention to words rather than participation. 19

As to the relationship of hot and cool media, McIuhan comments:

Any hot medium allows of less participation than a cool one, as a lecture makes for less participation than a seminar, and a book for less than dialogue. With print many earlier forms were excluded from life and art, and many were given strange new intensity. But our own time is crowded with examples of the principle that the hot form excludes, and the cool one includes.20

Assuming that there is a degree of creative participation on the part of the participant in print media, this author contends that magazines may be "hotter" than newsprint. This assumption derives from the observation that magazines are geared toward a specialized homogenous audience, with group norms to abide by, and therefore would demand even less participation than the readers of newspapers.

The apparent controversy in the various theories and studies indicate strengths and weaknesses in evaluating the role of mass media and the public's relationship with the media. To better utilize these information sources, further investigative studies of sources and audience analysis and the effects of mass communication in general should be performed to determine successful methods of evaluation. 


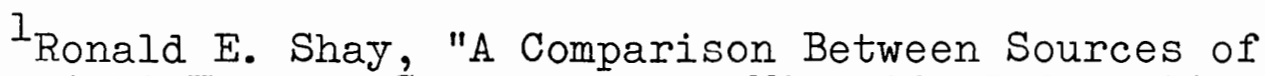
Student Anti-Hunting Sentiment and Wildlife Information Sources of a Sample of Oregon Adults" (M.S. thesis, Portland State University, 1974), p. 8.

$$
{ }^{2} \text { Ibid. } \quad 3 \text { Ibid. }
$$

${ }^{4}$ Earle H. MacCannell, "Mass Communication," study guide for upper division Sociology course, Portland State University, September 1977, p. 3.

5 Robert C. O'Hara, Media for the Millions (New York: Random House, 1962), p. II.

${ }^{6} \mathrm{John}$ C. Merrill and Ralph I. Lowenstein, Media, Messages, and Men (New York: David McKay Company, Inc., 1971), p. 8 .

7 Paul F. Lazarsfeld, Bernard Berelson, and Helen Gaudet, The People's Choice (New York: Duell, Sloan, and Pearce, 1944)

${ }^{8}$ Joseph T. Klapper, The Effects of Mass Communication (Glencoe, Illinois: The Free Press, 1960), p. 8.

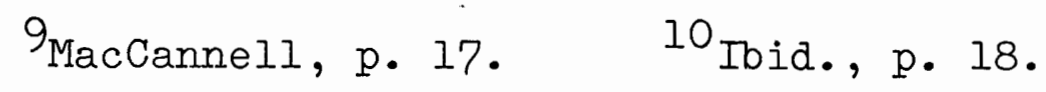

${ }^{11}$ Lewis A. Dexter and David M. White, People, Society, and Mass Communications (Iondon: Collier-MacMillan Lta., 1964), p. 69 .

12 Ibid.

13 Theodore Peterson, Magazines in the Twentieth Century (Urbana, Illinois: University of Illinois Press, 1975), p. 52 .

${ }^{14}$ Paul F. Lazarsfeld and Patricia Kendall, "The Communication Behavior of the Average American," Mass Communicants, ed. Wilbur Schramm (Urbana, Illinois: University of Illinois Press, 1960), pp. 425-437.

15 American Institute for Political Communication, The Effects of Local Media Monopoly on the Mass Mind (Washington, D.C.: January 1971), p. 24.

$$
\text { 16 Klapper, p. 110. 17 Ibid. } \quad{ }^{18} \text { Ibid., p. } 111 .
$$


${ }^{19}$ Peter M. Sandman, David B. Rubin, and David B. Sachsman, Media: An Introductory Analysis of American Mass Communication (Englewood Cliffs, New Jersey: Prentice-Hall Inc., 1972), p. 230. ${ }^{20}$ Marshall McLuhan, Understanding Media (New York: Signet Books, 1964), p. 37 . 


\section{PROBLEMS AND PROCEDURES}

\section{STATEMENT OF THE PROBLEN}

The specific problems investigated were:

1. From what source do a sample of subscribers of Oregon Wildlife obtain initial exposure to the magazine?

2. Which types of articles of those appearing in Oregon Wildlife are read by subscribers and to what extent are these articles read?

3. Is there a significant difference in occupation, age, and area of residence with regard to readership?

4. How accurately does the sample of subscribers assess Oregon Wildlife and how does this sample appraise the overall readability of the magazine?

5. Is there a relationship between the samples assessment of readability and accuracy of Oregon Wildlife and the extent of readership?

6. Is Klapper's reinforcement hypothesis valid in relation to this study?

\section{HYPOTHESIS TO BE TESTED}

Iittie investigation has been done concerning how individuals use the media in the field of fish and wildlife. 
Very few readership studies have been performed to determine what kind of readers read what kind of articles and why •

In study of the media's influence on the opinions, values, and behaviors of their audiences, findings have proposed that mass communication either has a hypodermic effect or a reinforcing effect on its audience.

The hypothesis to be tested by this study is:

Hypothesis: There will be no significant difference between reinforcement of how often general types of articles are read as compared to the sentiments of readability and accuracy of the magazine.

This null hypothesis was rejected based on Joseph Klapper's five generalizations on the effects of mass communication.

\section{DEFINITION OF TERMS}

1. Respondent. An individual who has completed enough data on a returned questionnaire to be totaled with the results. Questionnaires which were only partially completed were entered in the tabulations.

2. General Articles. Articles which generally appear in most issues of Oregon Wildlife magazine. General articles include: Monthly Meeting Information, "This and That," Wildlife Education, Wildlife Feature 
stories, Fish Feature Stories, Fish and Wildlife Regulations, Management Information, Suggested Books, and Editorials.

\section{A.SSUMPTIONS}

The following assumptions were made by the investigator in compiling this study.

It was necessary to assume that the completed and returned questionnaires which were used in this study are representative of the individual's sentiments. It was also assumed that this sample is representative of other subscribers who were not a part of the sample set.

The questionnaire was sent on the Oregon Wildlife Commission's stationery. Following Shay's study, it was assumed that the agency name together with the questionnaire, would not bias responses other than possible increase in returns.

PROCEDUR ES

\section{Sampling}

A one-page questionnaire, to be completed on both sides was mailed to a sample of subscribers of Oregon Wildlife, held by the Oregon Wildlife Commission's computerized IBM cards.

The sampling method was a systemized sample with a random start. This method was chosen because the filing 
system of subscribers is filed in the Oregon Wildlife Commission's computer alphabetically within each zip code. The individual maintaining the computer, randomly chose a starting point between the number one filed subscriber and the one hundreth subscriber. From here, one out of every one hundred of the remaining cards were chosen systematically.

Cochran pointed out the validity of a systemized sampling with a random start:

Systemized samples are convenient to draw and to execute. . they may give poor precision when unsuspected periodicity is present. In light of these results, systematic sampling can safely be recommended in the following situations: l-Where the ordering of the population is essentially random or contains at most a mild stratification. ${ }^{1}$

Since the ordering of the population was essentially random in the zip code filing, it was assumed for the purpose of this study, the method was appropriate.

Snedecor further comments on the justification of systematic sampling:

Systematic sampling has two advantages over simple random sampling. It is easier to draw, since only one random number is required and it distributes the sample more evenly over the listed population. For this reason systematic sampling often gives more accurate results than simple random sampling.?

It was decided to take one name out of each 100 in the computer to give the desired sample of 530, or just less than $1 \%$ of the total representative subscribers. 
The Questionnaire

The questionnaire was designed in part after the one used in the 1972 Western Speech Journal study. (See Appendix A.) Alterations were made to adapt to the nature of a fish and wildlife magazine, as opposed to the professional journal. In designing the questionnaire, Lazarsfeld's principles of "specification, division and tacit assumption" were taken into consideration. Iazarsfeld points out :

The principle of division does not mean that questions cannot, under some circumstances, be technical or complex; it means only that they should be understandable to the persons asked to respond to them. . . You must try to enable the respondent to answer in terms that he understands and within the context of his past experience. 3

In writing the questionnaire in terms which the readers could relate to and understand, the investigator had to assume the context of the readers.

Dichotomous, multiple choice and open-end question formation were used in the questionnaire according to Lazarsfeld's principle of specification. ${ }^{4}$

Oregon Wildlife published articles concerning the Oregon Wildlife Commission's monthly meetings, wildlife education, wildlife feature stories, fish feature stories, fish and wildlife regulations, management information, suggested books in the field of fish and wildlife, and editorial comments. The questionnaire includes a scale of measuring readership of these general articles as well 
as a similar scale measuring the readership of specific articles in each month's magazine. The participants were asked to disclose age, sex, locality in the state, and occupation. Further questions include how the reader heard about Oregon Wildlife, if the subscriber reads each issue, how many years the subscriber has been reading Oregon Wildlife, and how many people other than the subscriber read their copy. In addition, readers are asked to assess accuracy and readability of the magazine, if the reader subscribes to other wildlife oriented magazines, and if the subscriber has purchased a hunting or angling license within the past five years.

One-half of the total selection (265) were sent questionnaires after they had received the April 1977 issue. The remaining half were sent questionnaires after they had received the May 1977 issue. The first group of questionnaires were mailed on April 22, 1977. By waiting three weeks after the respondents were sent the magazine, it was assumed that each participant would have received the issue. The $265^{\circ}$ questionnaires pertaining to the May 1977 issue were divided into three time segments. Eighty-five questionnaires were mailed on May 9, 1977, ninety questionnaires were mailed on May 16, 1977, and the final ninety questionnaires were mailed on May 23. It was proposed that intermittent mailing of the questionnaires may have been an aid in determining whether the recipients vary in 
readership according to time in possession of the magazine. Since there was no way of determining how much time passed between the time the questionnaire was in the participant's possession and the time the completed questionnaire was returned to the Oregon Wildlife Commission, and the sample was not large enough to be significant, this question was deemed unmeasurable.

Included with the questionnaire was a cover letter from the Department of Fish and Wildlife (see Appendix A) and addressed return envelope. The mail was processed through a postage meter and the cover letter was a form letter signed by Ron Shay, the editor of Oregon Wildlife.

In February and March of 1978 all data were considered returned. To date, no further questionnaires have been returned. The data were tallied and filed into the computer. Data were key-punched onto IBM cards, and analyzed statistically.

Returned questionnaires marked "undeliverable" by the U.S. Postal Service, or otherwise unable to tally because of unclear responses, made up 6.5\%, or 19 of the 530 mailed. Table I indicates reasons why the returned and nondeliverables fell into that class. 
TABLE I

REASONS FOR NON-DELIVERY OF QUESTIONNAIRES

Reason Marked on Envelope

Number

Undeliverable as addressed,

Unable to forward, as indicated by

U.S. Post Office. . . . . . . . . . . •

Addressee Unknown, as indicated by

U.S. Post Office . • • • . • •

2

Deceased

Returned Blank.

Unable to Identify Responses

Total 
Chapter 3--Notes

${ }^{I}$ Ronald E. Shay, "A Comparison Between Sources of Student Anti-Hunting Sentiment and Wildlife Information Sources of a Sample of Oregon Adults" (M.S. thesis, Portland State University, 1974), p. 26.

2 Tbid.

3 Bernard C. Hennessy, Public Opinion (Belmont, California: Wadsworth Publishing Co., Inc., 1970), p. 104. ${ }^{4}$ Ibid., p. 106. 


\title{
CHAPTER IV
}

\author{
RESUITS \\ GENERAI RESULTS
}

\section{The Respondents}

1. Questionnaires were mailed to 530 individuals selected from the subscriber list of sixty-two thousand. Nineteen or $6.5 \%$ of the questionnaires were returned as undeliverable by the U.S. Postal Service, marked deceased, returned blank, or were otherwise unable to be tallied due to unclear responses.

2. Of the 292 questionnaires returned, 273 or $93 \%$ were returned with adequate information to tally. Two hundred sixty-five or $50 \%$ were mailed to respondents of April's issue. Two hundred sixty-five or $50 \%$ were also mailed to respondents of May's issue. Of the 265 mailed to April's sampling, 143 or $54 \%$ were returned and usable. Of the 265 which were mailed to May's sampling, 130 or $49 \%$ were returned and usable.

3. One hundred forty-three or $52 \%$ of the questionnaires were in response to April's issue. One hundred thirty or $48 \%$ were in response to May's issue.

4. Ages of the respondents ranged from 10 to 89. A plurality of respondents, or $25 \%$, ranged between the 
ages of 60 to 69 years.

5. Males made up $90 \%$ of the respondents, and females made up $7 \%$ of the respondents. Three percent of the two questionnaires were indicated as being filled out by both husband and wife jointly.

6. Of the respondents $57 \%$ indicated rural residences, $22 \%$ indicated residences in a metropolitan area, and the remainder indicated residence in a city of 10-50,000.

7. Of the respondents $32 \%$ indicated occupations in labor or trade, $36 \%$ indicated retirement, $13 \%$ in professional occupations, $6 \%$ indicated public service, $3 \%$ indicated administrative, $3 \%$ indicated sales, and $3 \%$ indicated not-employed. Occupations in research were indicated by $1 \%$ and $1 \%$ designated being students. Of the respondents $2 \%$ did not indicate occupation.

8. More than one-half of the respondents, or $51 \%$ indicated hearing about Oregon Wildlife from a friend. In descending order, other sources mentioned were: at the store (14\%), other $(8 \%)$, cannot remember $(7 \%)$, at a meeting (5\%), relative (4\%), at work (3\%), on the radio and from a teacher (both $1 \%$ ), and blank answer (5\%). The category of "other" responses were written-in responses including: "subscribe from the beginning of Oregon Wildlife," "state fair," "through license purchase," "boat show," "OMSI," "Iibrary," "mail," "newspaper," 
"doctor's office," "Hunter's Safety course," and "sorting mail in the Post Office."

9. Of the respondents $95 \%$ designated that they did read each issue, $4 \%$ indicated that they did not read each issue, and $1 \%$ did not reply to this question.

\section{General Readership of}

\section{Oregon Wildlife}

When asked to determine the frequency of readership of the general types of articles which occur in Oregon Wildlife, $54 \%$ responded to having read the general types of articles "always." Twenty-eight percent "nearly always" read the general types of articles, 12\% "rarely," $2 \%$ "never," and 4\% did not respond. Wildlife Feature stories were read by $79 \%$, or most often checked as being read "always." Management Information was checked most often as being read "nearly always" (38\%). Suggested Books was checked most often as being read "rarely" (40\%), as well as most often being checked "never" (10\%). Summarized data are found in Table II. 


\section{TABLE II}

GENERAL ARTICLES AND HOW OFTEN READ

\begin{tabular}{|c|c|c|c|c|c|c|c|c|c|c|}
\hline \multirow{2}{*}{$\begin{array}{l}\text { General } \\
\text { Articles }\end{array}$} & \multicolumn{2}{|c|}{ Always } & \multicolumn{2}{|c|}{$\begin{array}{l}\text { Nearly } \\
\text { Always }\end{array}$} & \multicolumn{2}{|c|}{ Rarely } & \multicolumn{2}{|c|}{ Never } & \multicolumn{2}{|c|}{$\begin{array}{c}\text { No } \\
\text { Answer }\end{array}$} \\
\hline & No. & $\%$ & No. & $\%$ & No. & $\%$ & No. & $\%$ & No. & $\%^{2}$ \\
\hline $\begin{array}{l}\text { Monthly Meeting } \\
\text { Information }\end{array}$ & 90 & 33 & 81 & 30 & 76 & 28 & 14 & 5 & 12 & 4 \\
\hline "This and That" & 150 & 55 & 91 & 33 & 13 & 5 & 2 & 1 & 17 & 6 \\
\hline $\begin{array}{l}\text { Wildlife } \\
\text { Education }\end{array}$ & 171 & 63 & 73 & 27 & 17 & 6 & 2 & 1 & 10 & 4 \\
\hline $\begin{array}{l}\text { Wildilfe } \\
\text { Feature } \\
\text { Stories }\end{array}$ & 217 & 79 & 45 & 16 & 3 & 1 & 0 & 0 & 8 & 3 \\
\hline $\begin{array}{l}\text { Fish Feature } \\
\text { Stories }\end{array}$ & 184 & 67 & 58 & 21 & 19 & 7 & 3 & 1 & 9 & 3 \\
\hline $\begin{array}{l}\text { Fish and Wild- } \\
\text { life Regula- } \\
\text { tions }\end{array}$ & 181 & 66 & 69 & 25 & 14 & 5 & 2 & 1 & 7 & 2 \\
\hline $\begin{array}{l}\text { Management } \\
\text { Information }\end{array}$ & 133 & 49 & 104 & 38 & 23 & 8 & 2 & 1 & 11 & 4 \\
\hline $\begin{array}{l}\text { Suggested } \\
\text { Books }\end{array}$ & 52 & 19 & 68 & 25 & 110 & 40 & 27 & 10 & 16 & 6 \\
\hline Editorials & 148 & 54 & 88 & 32 & 25 & 9 & 3 & 1 & 9 & 3 \\
\hline Total & 1326 & & 677 & & 300 & & 55 & & 99 & \\
\hline
\end{tabular}

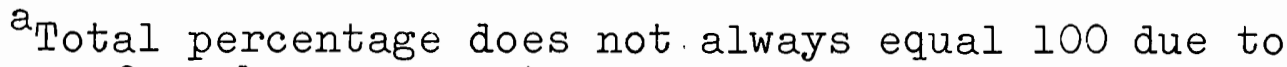
rounding of numbers. 
Specific Readership of

Oregon Wildlife

Those who were mailed the questionnaire pertaining to April's issue were asked to designate the amount of readership of the seven specific articles printed in the April issue. Of the articles, "The Big Dumping Grounds in the Sea" fits under the general article category of Editorial. "Commission Meetings" was considered Monthly Meeting Information, "'200 Mile Zone-FCMA-Regional Councils-RCA' What Do These Terms Mean to Oregonians?" and "Sandy Smelt" are Fish Feature Stories. "Birds in the Bush - And Elsewhere" is a Wildlife Feature Story. "Sauvie Island Christmas Bird Count December 19, 1976" is considered Wildlife Education, and "New Regulations Govern Bay Clam Digging" is a Fish and Wildlife Regulation article.

It was answered by the total of April's sampling that each of the specific articles were most often "all" being read. Specific articles were checked: "All" 58\%, "Part" 20\%, "Title" 7\%, "Don't Remember" 5\%, "None" 6\%, and No Answer 4\%. "Sandy Smelt" was checked most often as having "all" been read, at 74\%. "Birds in the Bush - And Elsewhere" was most often checked "part" read, at 26\%. "Commission Meetings" and "Sauvie Island Christmas Bird Count December 19, 1976" were both checked by 15\% as having most often read the. "title" only: "Commission Meeting" was also most often not remembered at $16 \%$ checked for both categories of "don't remember" and "none." Specific data may be found in Table III. 
TABLE III

SPECIFIC ARTICLES FROM APRII, 1977 ISSUE AND HOW OFTEN READ

\begin{tabular}{|c|c|c|c|c|}
\hline \multirow{2}{*}{ Specific Articles } & \multicolumn{2}{|c|}{ All } & \multicolumn{2}{|c|}{ Part } \\
\hline & No. & & No. & $\%$ \\
\hline $\begin{array}{l}\text { "The Big Dumping Grounds } \\
\text { in the Sea" (Editorial) }\end{array}$ & 92 & 64 & 31 & 22 \\
\hline "Commission Meetings" & 54 & 38 & 33 & 23 \\
\hline $\begin{array}{l}\text { "'200 Mile Zone-FCMA- } \\
\text { Regional Councils-RCZ' What } \\
\text { Do These Terms Mean to } \\
\text { Oregonians?" }\end{array}$ & 93 & 65 & 28 & 20 \\
\hline "Sandy Smelt" & 106 & 74 & 20 & 14 \\
\hline $\begin{array}{l}\text { "Birds in the Bush and } \\
\text { Elsewhere" }\end{array}$ & 76 & 53 & 37 & 26 \\
\hline $\begin{array}{l}\text { "Sauvie Island Christmas } \\
\text { Bird Count December 19, } \\
\text { 1976" (Iist) }\end{array}$ & 70 & 49 & 31. & 22 \\
\hline $\begin{array}{l}\text { "New Regulations Govern } \\
\text { Bay Clam Digging" }\end{array}$ & 94 & 66 & 23 & 16 \\
\hline Total & 585 & & 203 & \\
\hline
\end{tabular}


TABIE III--Continued

\begin{tabular}{|c|c|c|c|c|c|c|c|c|}
\hline \multicolumn{2}{|c|}{ Title } & \multicolumn{2}{|c|}{ Don't Remember } & \multicolumn{2}{|c|}{ None } & \multicolumn{2}{|c|}{ No Answer } & \\
\hline No. & $\%$ & No. & $\%$ & No. & $\%$ & No. & $\% a$ & \\
\hline 1 & 1 & 10 & 7 & 2 & 1 & $?$ & 5 & ! \\
\hline 15 & 10 & 16 & 11 & 16 & 11 & c & 6 & \\
\hline 5 & 3 & 8 & 6 & 4 & 3 & 5 & 3 & \\
\hline 5 & 3 & 2 & 1 & 4 & 3 & $\epsilon$ & 4 & \\
\hline 8 & 6 & 5 & 3 & 9 & 6 & $\varepsilon$ & 6 & \\
\hline 15 & 10 & 7 & 5 & 15 & 10 & 5 & 3 & \\
\hline 11 & 8 & 4 & 3 & 6 & 4 & 5 & 3 & \\
\hline 60 & & 52 & & 56 & & 44 & & \\
\hline
\end{tabular}

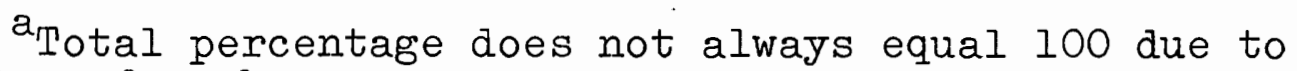
rounding of numbers. 
Those answering the May issue questionnaire were asked for responses on eleven articles which appeared in the May issue. Five of the eleven specific articles consisted of lists. The five lists as well as the article on "1976 Big Game Hunting Seasons," were all considered Wild: life Feature Stories. "Let the Punishment Fit the Crime," was the only editorial in the May issue. "Piscatorial Parenthood of the Lingcod," and "Test Fishing" were both Fish Feature Stories. "Commission Meetings" and "Local Town Hall Meetings" fit under the general category of Monthly Meeting Information.

In response to May's questionnaire, as well as April's questionnaire, "all" was most often checked, at 58\%, as the amount of each specific article read.

May's questionnaire differed from April's questionnaire in specific articles, as well as in categories of the types of articles generally appearing in Oregon Wildlife. In both month's issues, there were no specific articles on "This and That," Suggested Books, or Management Information. In both April and May issues, there was one article in each which was an Editorial. May's issue had two articles concerning Monthly Meeting Information, as opposed to April's which only had one article on Monthly Meeting Information. Both issues had two articles on Fish Feature Stories. May had four lists and one article on Wildlife Feature Stories, whereas the April issue only had one Wildlife Feature story 
article. April also had the only article on Wildlife Education as well as the only article on Fish and Wildlife Regulations.

"Let the Punishment Fit the Crime" was the most popular article, as being checked by $88 \%$ of the sample as having been "all" read. "Deer Hunting Trends 1952-1976" (List) was read $28 \%$, or most often "part" read. In the "Local Town Hall Meetings" article, the "title" was read 15\%, or most often, as well as the article most often not remembered. Summarized data may be found in Table IV. 


\section{TABLE IV}

SPECIFIC ARTICLES FROM MAY, 1977 ISSUE AND HOW OFTEN READ

Specific Articles

"Let the Punishment Fit the Crime"

"Commission Meetings"

"1976 Big Game Hunting Seasons"

"1976 Deer Season" (Iist)

"1976 Elk Season". (List)

"Deer Hunting Trends 19521976" (List)

"Elk Hunting Trends 19331976" (List)

"1976 Antelope Season (74\% Report Card Return)" (List)

"Piscatorial Parenthood of the Lingcod"

"Test Fishing"

"Local Town Hall Meetings"

Total

\begin{tabular}{|cc|cc}
\hline \multicolumn{2}{|c|}{ All } & \multicolumn{2}{|c}{ Part } \\
\hline No. & $\%$ & No. & $\%$ \\
\hline 114 & 88 & 10 & 8 \\
61 & 47 & 29 & 22 \\
87 & 67 & 21 & 16 \\
85 & 65 & 24 & 18 \\
72 & 55 & 26 & 20 \\
76 & 58 & 36 & 28 \\
67 & 52 & 30 & 23 \\
& & & \\
49 & 38 & 29 & 22 \\
85 & 65 & 15 & 12 \\
49 & 60 & 24 & 18 \\
\hline 823 & 19 & 15 \\
\hline
\end{tabular}


TABIE IV--Continued

\begin{tabular}{|c|c|c|c|c|c|c|c|}
\hline \multicolumn{2}{|c|}{ Title } & \multicolumn{2}{|c|}{ Don't Remember. } & \multicolumn{2}{|c|}{ None } & \multicolumn{2}{|c|}{ No Answer } \\
\hline No. & $\%$ & No. & $\%$ & No. & $\%$ & No. & $\% a$ \\
\hline 0 & 0 & 2 & 1 & 0 & 0 & 4 & 3 \\
\hline 10 & 8 & 14 & 11 & 7 & 5 & 9 & 7 \\
\hline 6 & 5 & 1 & 1 & 7 & 5 & 8 & 6 \\
\hline 8 & 6 & 1 & 1 & 5 & 4 & 7 & 5 \\
\hline 11 & 8 & 4 & 3 & 7 & 5 & 10 & 8 \\
\hline 5 & 4 & 4 & 3 & 4 & 3 & 5 & 4 \\
\hline 14 & 11 & 4 & 3 & 7 & 5 & 8 & 6 \\
\hline 18 & 14 & 7 & 5 & 18 & 14 & 9 & 7 \\
\hline 13 & 10 & 4 & 3 & 5 & 4 & 8 & 6 \\
\hline 6 & 5 & 12 & 9 & 4 & 3 & 6 & 5 \\
\hline 19 & 15 & 19 & 15 & 16 & 12 & 8 & 6 \\
\hline 110 & & 72 & & 80 & & 82 & \\
\hline
\end{tabular}

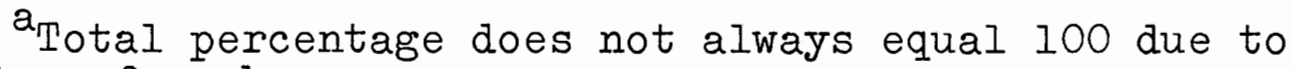
rounding of numbers. 


\section{THE RESPONDENTS}

The recipients of the questionnaire were asked to indicate their age, sex, occupation, and town or city in which they live, designating specifically whether they live in a metropolitan area, a city of 10,000 to 15,000 , or a rural area.

The response indicated a bias toward males. Male respondents constituted $90 \%$ of the total sample, while female respondents constituted only $7 \%$ of the sample. Two questionnaires were completed by both husband and wife jointly.

A tally of age of the respondents and frequencies may be found in Table V. A plurality of respondents were found to fall between the ages of 50 to 69 , with $20 \%$ of the respondents between 50 and 59, and 25\% between 60 and 69 . As suggested by Bigelow, the sample was broadened to include young people, 14 to 20 years of age. ${ }^{1}$ 


\section{TABLE V}

AGES OF RESPONDENTS

\begin{tabular}{ccc}
\hline Age & Number & Percent \\
\hline $10-19$ & 7 & 3 \\
$20-29$ & 18 & 7 \\
$30-39$ & 36 & 13 \\
$40-49$ & 36 & 13 \\
$50-59$ & 55 & 20 \\
$60-69$ & 69 & 25 \\
$70-79$ & 36 & 13 \\
$80-89$ & 11 & 4 \\
No answer & 5 & 2 \\
\hline
\end{tabular}

Occupational categories of respondents were partially based on the Occupational Classification of the Department of Labor. ${ }^{2}$ The eight categories considered were professional, labor/trade, public service, sales, student, research, retired, and unemployed.

Professional occupations include occupations in law, education, medicine, engineering, religion, art, administrative specializations, managers, and executives. Labor/ trade occupations include occupations in carpentry, mechanics, clerical, service in food and lodging, farming, and logging. Public Service occupations include state employees such as foresters, police officers, and government 
affiliated professions. Sales occupations include salespersons in commodities, insurance, and merchandising. Students range from grade school through college. Research occupations include fields of education, industry, and business.

Retired respondents constituted 99 of the 273, or a plurality of respondents who answered the occupational question. Eight respondents designated that they were unemployed, and five respondents did not answer the occupational question. A tally of the occupational divisions may be found in Table VI.

\section{TABLE VI}

\section{OCCUPATIONAL DIVISIONS}

\begin{tabular}{lcc}
\hline \multicolumn{1}{c}{ Occupation } & Number & Percent $^{\mathrm{a}}$ \\
\hline Professional & 44 & 16 \\
Labor/trade & 87 & 32 \\
Public Service & 16 & 6 \\
Sales & 7 & 3 \\
Student & 4 & 1 \\
Research & 3 & 1 \\
Retired & 99 & 36 \\
Unemployed & 8 & 3 \\
No answer & 5 & 2 \\
\hline
\end{tabular}

$a_{\text {Total }}$ percentage does not always equal 100 due to rounding of numbers. 
Area of residence was broken into the three categories of a metro area, or a city with a population larger than 50,000; a city of 10,000 to 50,000; and a rural area. The majority of the respondents, 57\%, indicated living in a rural area. Summarized data on residence are found in Table VII.

\section{TABLE VII}

AREA OF RESIDENCE

\begin{tabular}{ccc}
\hline \hline Area & Number & Percenta \\
\hline Metro area & 61 & 22 \\
City of 10,000 to & 52 & 19 \\
50, 000 & 156 & 57 \\
Rural area & 5 & 2 \\
No answer & 56 \\
\hline
\end{tabular}

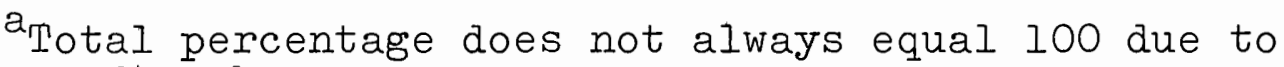
rounding of numbers.

\section{SOURCES OF INFORMATION}

Results of the survey indicate that the respondents most often first heard about Oregon Wildlife from a friend, and least often from the radio or teachers. The questionnaire allowed for responses of "friend," "radio," "at a meeting," "saw at a store," and "other." It was necessary to categorize four additional sources as a result of responses to "other." The additional sources include: 
"relative," "work," and "cannot remember." Table VIII designates source information comparison.

\section{TABIE VIII}

SOURCE OF INFORMATION COMPARISON

\begin{tabular}{lcc}
\hline \multicolumn{1}{c}{ Source } & Number & Percenta \\
\hline Friend & 140 & 51 \\
Radio & 3 & 1 \\
Meeting & 15 & 5 \\
Store & 37 & 14 \\
Relative & 12 & 4 \\
Work & 7 & 3 \\
Teacher & 3 & 1 \\
Cannot remember & 19 & 7 \\
Other & 22 & 8 \\
No answer & 15 & 5 \\
\hline
\end{tabular}

Total percentage does not always equal 100 due to rounding of numbers.

\section{READERSHIP OF ISSUE}

In response to the question "Do you read each issue," 95\% of the respondents answered "yes," 4\% answered "no," and 1\% did not answer. A tally of those other than the sample who read the respective respondent's issue may be found in Table IX. 
TABLE IX

READERSHIP OF SAMPLE'S ISSUE

O'PHER THAN RESPONDENT

\begin{tabular}{ccc}
\hline Other Readers & Number & Percenta \\
\hline 1 & 104 & 38 \\
2 & 80 & 29 \\
3 & 31 & 11 \\
4 & 16 & 6 \\
5 & 3 & 1 \\
6 & 1 & 1 \\
More & 8 & 3 \\
None & 13 & 5 \\
No answer & 17 & 6 \\
\hline
\end{tabular}

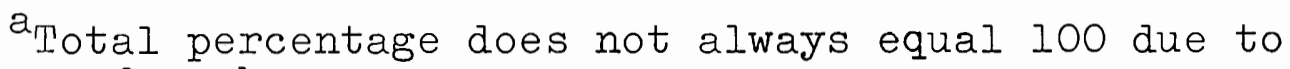
rounding of numbers.

The response tally to the question pertaining to how many years the respondent has been reading Oregon Wildilfe may be found in Table $X$. 
TABLE $X$

NUMBER OF YEARS RESPONDENT HAS BEFN

READING OREGON WILDIIFE

\begin{tabular}{ccc}
\hline Years & Number & Percent $^{2}$ \\
\hline $1 / 2$ & 13 & 5 \\
1 & 12 & 4 \\
2 & 13 & 5 \\
3 & 22 & 8 \\
4 & 20 & 7 \\
5 & 35 & 13 \\
More & 152 & 56 \\
No answer & 6 & 1 \\
\hline
\end{tabular}

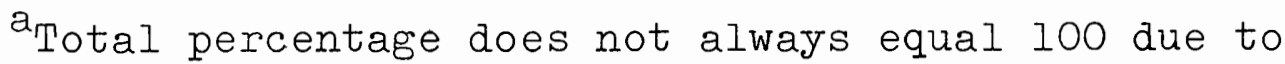
rounding of numbers.

\section{ACCURACY AND READABILITY}

The sample of subscribers to Oregon Wildlife response to accuracy and readability has a high correlation with the amount of readership of general as well as specific articles.

Of the respondents $94 \%$ designate that Oregon Wildlife describes and represents what is going on in the field throughout the state, either "very accurately" or "fairly accurately": 38\% constitute "very accurately" responses, while 56\% constitute "fairly accurately" responses. Only $2 \%$ of the sample designate "not very accurately" and less than $1 \%$ designate "not accurately at all." 
Readability or style of writing responses were also positive. The majority readability appraisable, or $86 \%$ response was that the style of writing of Oregon Wildlife is "about right." No respondents suggest that Oregon Wildlife is too complex, nor too simple. Only $4 \%$ designate the readability as "fairly complex," and $7 \%$ designate the readability "quite simple." Three percent of the sample did not answer this question relating to readability. In order to further investigate the credibility, accuracy, and readability of Oregon Wildlife, professors of biology, fish and wildlife were contacted by telephone on April 24, 1978. The sample consisted of six professors based on the limited availability of professors in the field within the state. Of the six professors contacted, two were from Oregon State University's School of Agriculture, Department of Fisheries and Wildlife; one from Southern Oregon State College, Biology department; one from the University of Oregon, Biology department; one from Oregon College of Education, Natural Science department; and one from Portland State University, Biology department.

Professors were questioned as to whether or not they subscribe to Oregon Wildlife or are exposed to the magazine; if the professor is a hunter or fisherman; how accurately the professor feels Oregon Wildlife represents what is taking place in the field; how each professor would rate the overall readability or style of writing; and any 
further comments which each interviewee felt would better explain their viewpoint.

Of the total six professors sampled, five subscribe to Oregon Wildlife, or receive the magazine in their department. One does not subscribe, although he is occasionally exposed to issues. Five professors hunt or fish, and one does not currently hunt or fish, but has in the past. Accuracy was rated by four professors as "very accurately" and two professors rated Oregon Wildlife's representation as "fairly accurate." The total sample rated readability "about right."

Comments included observations that Oregon Wildlife (1) "performs a good job of covering important issues," (2) "may be a little too biological," (3) "should spend more time in trying to anticipate what will be happening in the field," (4) "material covered is clever and interesting," and (5) "should publish articles by experts in the field." Further comments suggested that several of the professors sampled use Oregon Wildlife extensively, including in the classroom. All respondents sampled expressed overall pleasure and satisfaction with the magazine.

SUBSCRIPTION TO OTHER MAGAZINES AND PURCHASE OF HUNTING OR ANGLING LICENSE

Of the total sample of subscribers to Oregon Wildlife, 4.7\% indicated subscription to other related magazines. Fifty-two percent of the sample do not subscribe to other 
magazines. One percent of the sample did not respond as either subscribing or not subscribing to other magazines.

It is suggested in the final responses, relating to purchase of hunting or angling licenses, that the majority of the sample are either hunters or fishermen. Of the respondents $86 \%$ designate purchase of a license within the past five years, while only $9 \%$ have not purchased a hunting or angling license within the past five years. Four percent of the responses were categorized as being retired. According to the Department of Fish and Wildlife, retired individuals are issued licenses free, therefore it would not be necessary to purchase a license. One percent of the respondents did not answer the question pertaining to purchase of licenses.

\section{INDEPENDENT VARIABLES OF RESPONDENTS AND GENERAL ARTICLES}

Independent variables of respondents include: age, occupation, locality in state, source exposure to Oregon Wildlife, and appraisal of accuracy and readability to the general types of articles appearing in Oregon Wildlife. General articles include: Monthly Meeting Information, "This and That," Wildlife Education, Wildlife Feature Stories, Fish Feature Stories, Fish and Wildlife Regulations, Management Information, Suggested Books, and Editorials. 
In comparing the independent variables of respondents and general articles, it was found that overall, respondents for all categories most often "always" or "nearly always" read seven of the nine general articles excluding the Monthly Meeting. Information and Suggested Books articles.

Evaluation breakdown of source exposure, readability, and accuracy will be further discussed. Since the breakdown of remaining variables is not relevant to this study, yet may be helpful for further investigation, a breakdown of the comparison findings may be found in Appendix B.

Comparison of Source Exposure,

Readability, and Accuracy

Appraisal to General

Articles

Relating to Klapper's stance on the reinforcement effect, tables and figures have been presented with further suggestion on the reinforcement topic.

Several comparisons were made relating to: (I) from which source the respondent was first exposed to Oregon Wildlife, and how often the respondent reads the nine general types of articles; (2) how the respondent appraises the accuracy of the magazine, and how often the respondent reads the nine general types of articles; and (3) how the respondent appraises the overall readability of Oregon Wildlife, and how often the respondent reads the general types of articles. 
Two tables and two figures were developed to designate the difference in breakdowns of the sample. It is important to note that the percentages listed are not based on the number of respondents, but rather on the amount of responses to the nine general types of articles.

\section{Source Exposure and}

General Articles

Table XI presents the overall findings comparing the sample's source of exposure and how often the general types of articles are read. Percentages were determined by totaling the source exposure. Figure 1 presents the breakdown of comparison between the categories of "friend," "radio," and "other." "Other" sources include: at a meeting, from a store, relative, work, teacher, cannot remember, other, and no answer.

According to the findings listed in Table XI, percentage-wise, those who hear about the magazine on the radio, most often read the articles "always" or "nearly always." Figure 1 seems to represent radio as the most positive persuasive mediator, although it should be taken into consideration that $51 \%$ of the respondents heard about Oregon Wildlife from a friend, whereas only $1 \%$ designate exposure to the magazine from the radio. Figure 1 also presents responses from those who were exposed to Oregon Wildlife by the radio with the least negative response. 


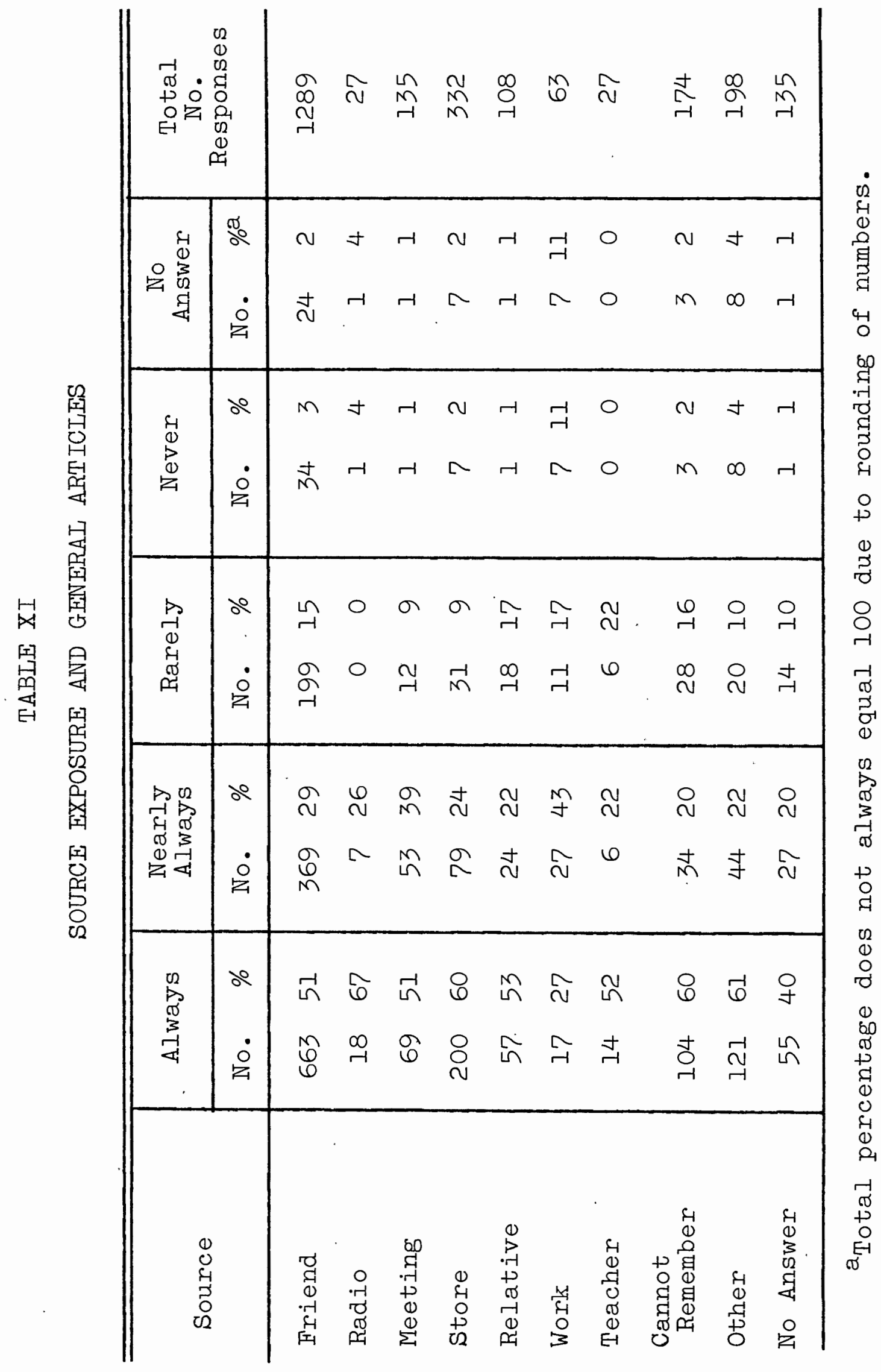




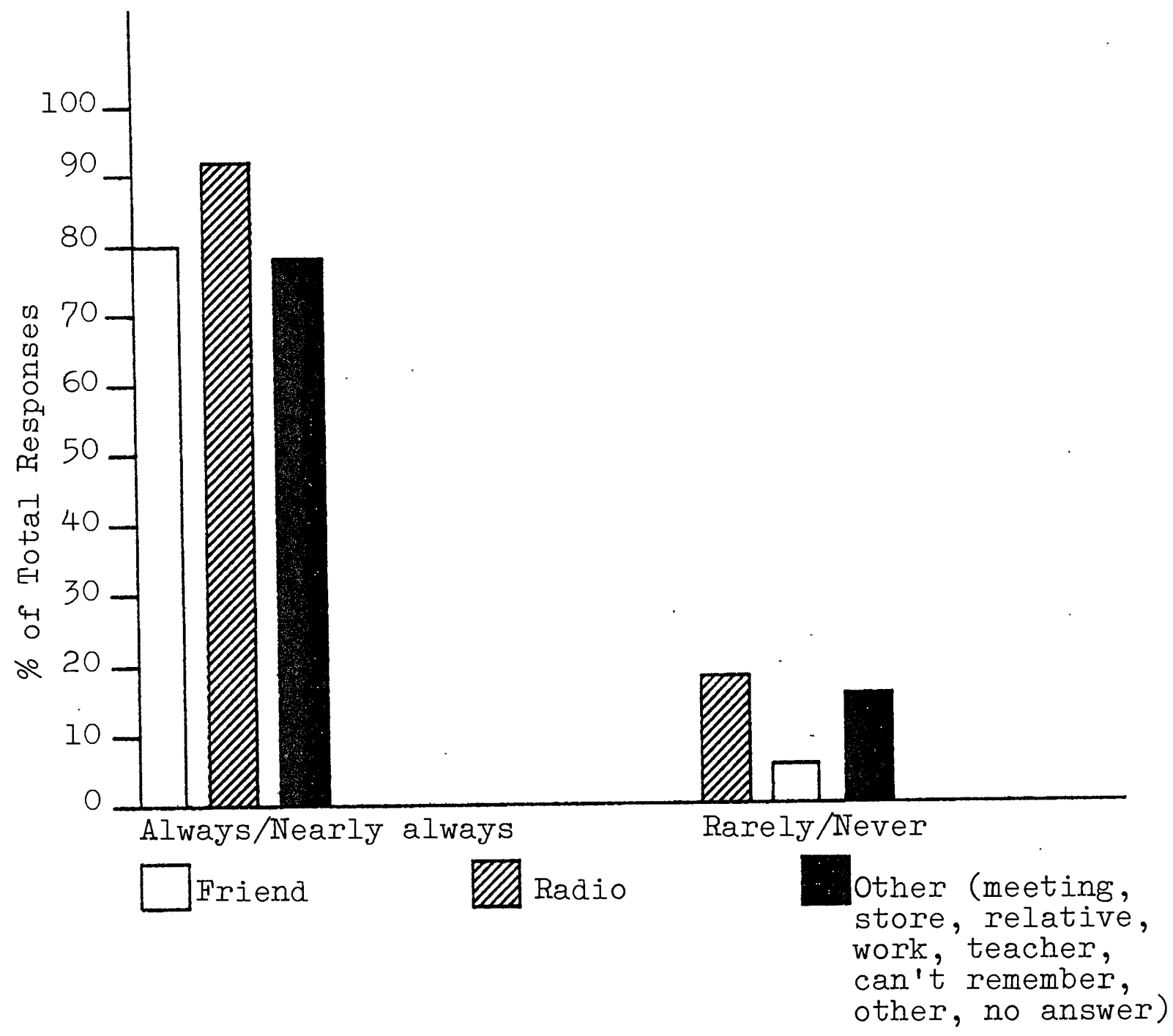

Figure 1. Histogram comparing source exposure and general types of articles read. 
Table XII also presents comparison figures of source exposure and general types of articles. Percentages were determined by totaling how often the general types of articles are read.

Figure 2 also presents a breakdown of "friend," "radio," and "other" categories, although "always," "nearly always," "rarely," and "never" responses are not distinguished. As apparent in Figure 2, those in the sample who were exposed to Oregon Wildlife by a friend, as opposed to other categories and especially the radio category, most often responded "always" or "nearly always" reading the general types of articles, as well as "rarely" and "never" reading the general types of articles.

Klapper found that personal influence is found more effective in persuasion than radio. In reviewing the laboratory experiments obtained by Lazarsfeld, Berelson, and Gaudet, Klapper explains:

Personal influence - here informal, as opposed to the formal lectures of the laboratory studies was observed to be more effective than radio, which was in turn observed to be more effective than print. The investigators advance various conjectural bases for this hierarachy, most of which concern the degree to which the audience member is personally involved or feels himself to be personally involved in the communication situation. Such conditions, the author believe, are at their height in personal contact, are reduced in radio listening, and are still lower in reading. 3

Although Figure 2 may suggest personal influence most often persuading exposure to the media, personal 
influence also most often corresponds to negative responses. This topic will be further discussed in the Summary. 
TABLE XII

GENERAI ARTICLES AND SOURCE EXPOSURE

\begin{tabular}{|c|c|c|c|c|c|c|c|c|c|c|}
\hline \multirow[t]{2}{*}{ Source } & \multicolumn{2}{|c|}{ Always } & \multicolumn{2}{|c|}{$\begin{array}{l}\text { Nearly } \\
\text { Always }\end{array}$} & \multicolumn{2}{|c|}{ Rarely } & \multicolumn{2}{|c|}{ Never } & \multicolumn{2}{|c|}{$\begin{array}{c}\text { No } \\
\text { Answer }\end{array}$} \\
\hline & No. & $\%$ & No. & $\%$ & No. & $\%$ & No. & $\%$ & No. & $\% a$ \\
\hline Friend & 663 & 50 & 369 & 55 & 199 & 59 & 34 & 54 & 24 & \\
\hline Radio & 18 & 1 & 7 & 1 & 0 & 0 & 1 & 2 & 1 & 1 \\
\hline Meeting & 69 & 5 & 53 & 8 & 12 & 4 & 1 & 2 & 0 & $\mathrm{O}$ \\
\hline Store & 200 & 15 & 79 & 12 & 31 & 9 & 7 & 11 & 15 & 15 \\
\hline Relative & 57 & 4 & 24 & 4 & 18 & 5 & 1 & 2 & 8 & 8 \\
\hline Work & 17 & 1 & 27 & 4 & 11 & 3 & 7 & 11 & 1 & 1 \\
\hline Teacher & 14 & 1 & 6 & 1 & 6 & 2 & 0 & 0 & 1 & 1 \\
\hline $\begin{array}{l}\text { Cannot } \\
\text { Remember }\end{array}$ & 104 & 8 & 34 & 5 & 28 & 8 & 3 & 5 & .5 & 5 \\
\hline Other & 121 & 9 & 44 & 7 & 20 & 6 & 8 & 13 & 5 & \\
\hline No Answer & 55 & 4 & 27 & 4 & 14 & 4 & 1 & 2 & 38 & 39 \\
\hline Total & 1318 & & 670 & & 339 & & 63 & & 98 & \\
\hline
\end{tabular}

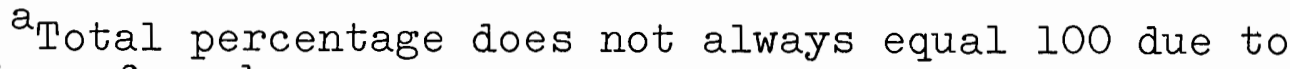
rounding of numbers. 


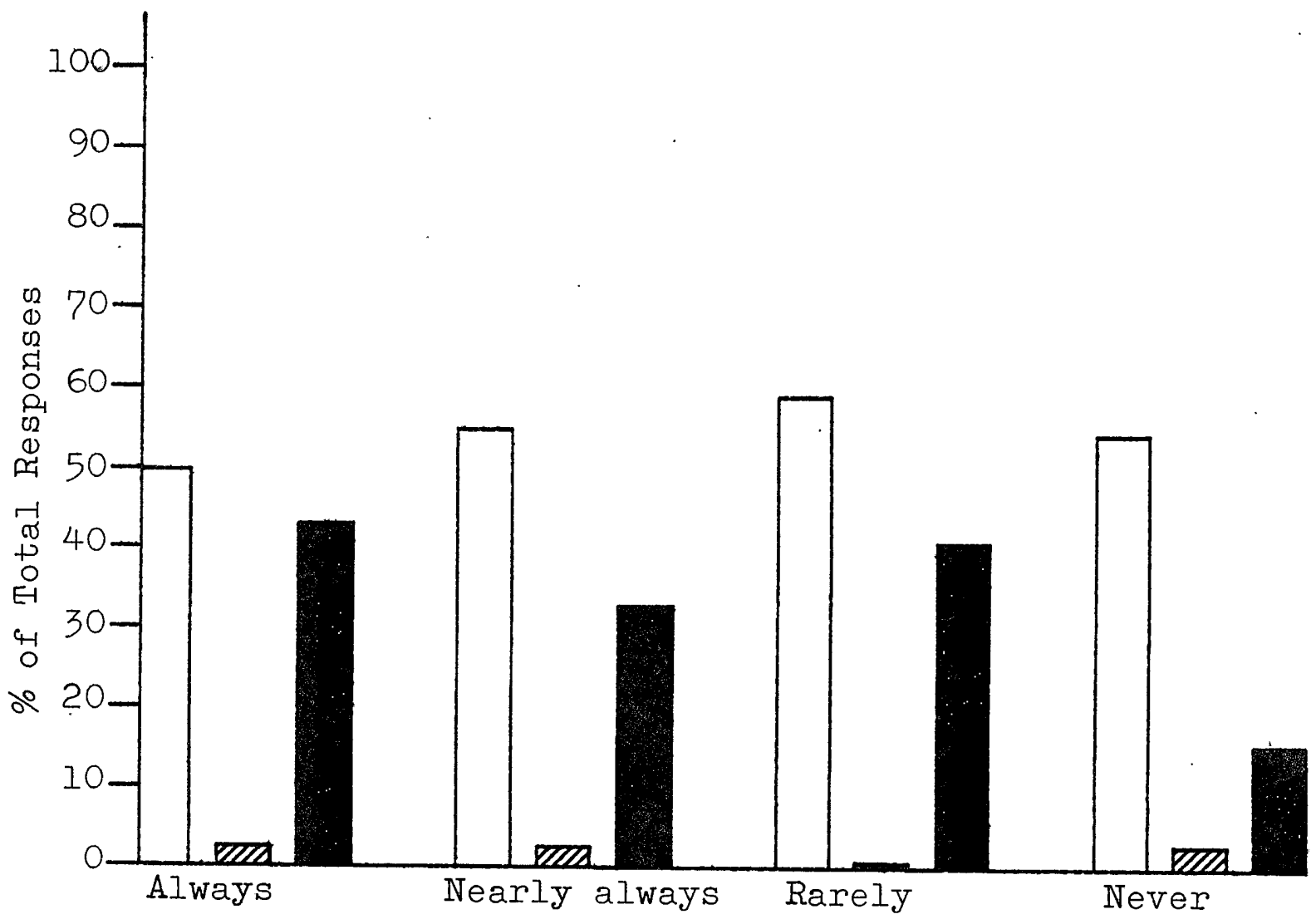

Friend

Radio

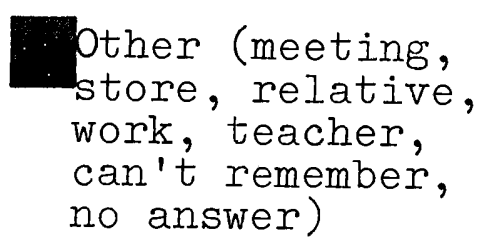

Figure 2. Histogram comparing general types of articles read and source exposure. 
Accuracy Apprajsal and

General Articles

Table XIII presents the overall findings comparing the sample's appraisal of accuracy and how often the cumulative types of articles are read. Percentages were determined by totaling accuracy appraisal. Figure 3 presents the breakdown of the categories of "very accurately," "fairly accurately," "not very accurately," and "not accurately at all."

It appears from Figure 3 that percentage-wise, those who appraise the accuracy of Oregon. Wildlife as "not accurately at all," most often "always" or "nearly always" read the general types of articles. It is important to note that $77 \%$ of the total respondents appraise the magazine as "very" or "fairly accurately," while only $2 \%$ of the respondents who appraise Oregon Wildlife as "not very accurately" or "not accurately at all," read the cumulative articles "always" or "nearly always." This figure is therefore open to misinterpretation if it is not taken into consideration the difference in size of sample responses. 


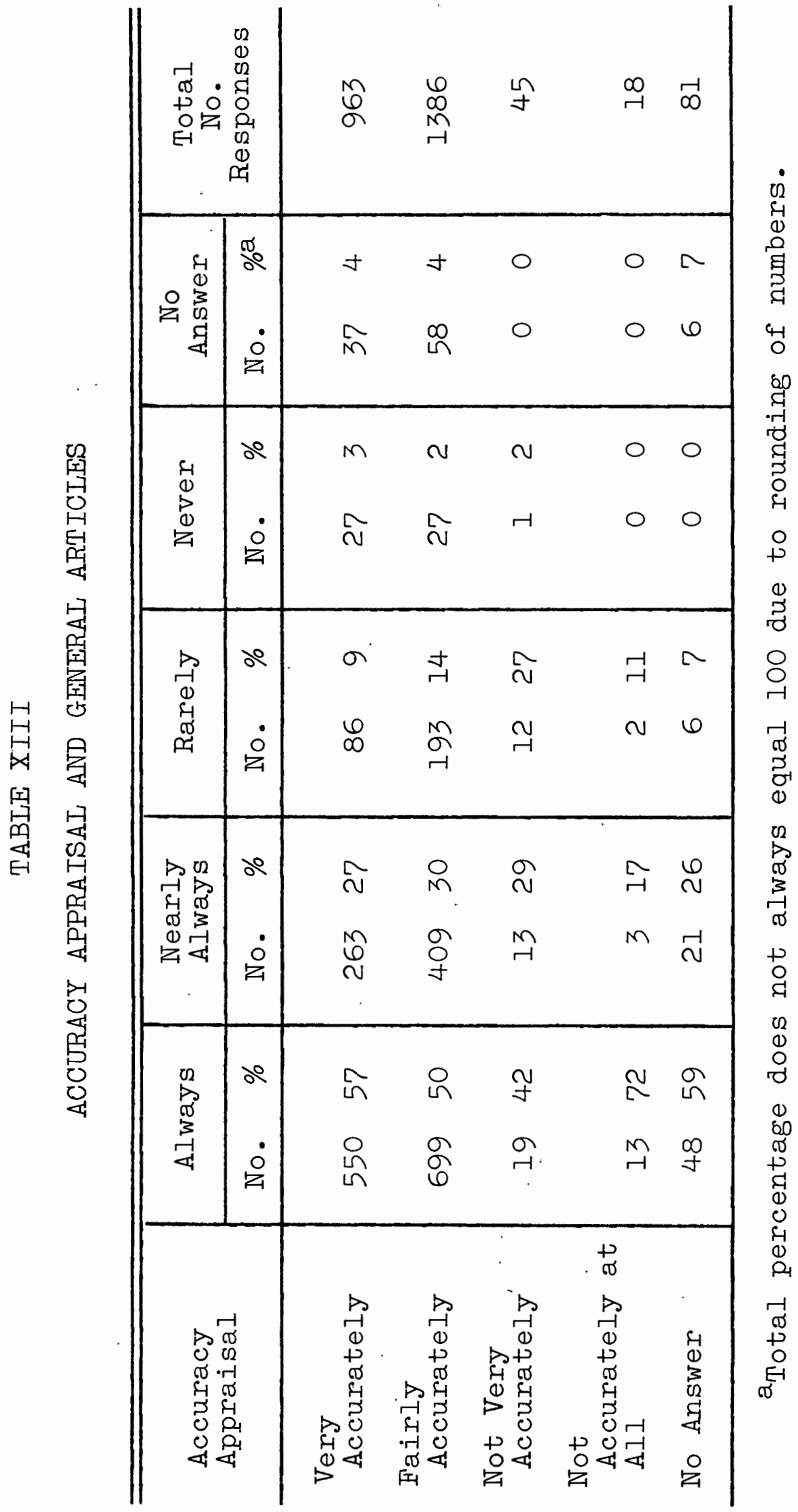




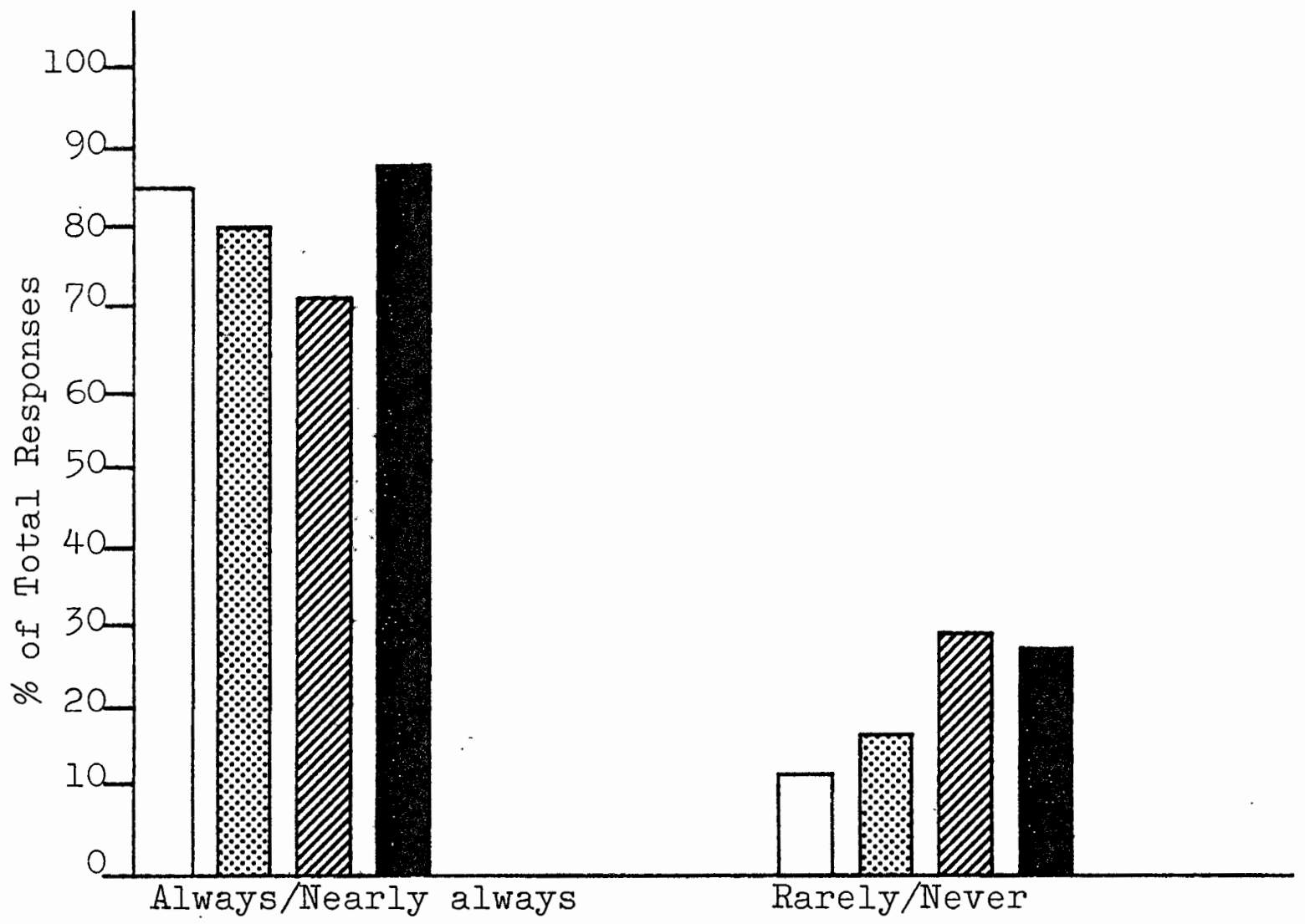

$\square$ Very accurately Not very accurately

Fairly accurately Not accurately at all

Figure 3. Histogram comparing accuracy appraisal and general types of articles read. 
Table XIV and Figure 4 present a more accurate overall picture of the relationship between responses to general types of articles and accuracy appraisal.

Approximately $94 \%$ of those respondents who feel Oregon Wildlife represents what is going on in the field "very" or "fairly accurately," read the articles "always" or "nearly always." Only $2 \%$ of those who responded "not very accurately" or "not accurately at all" to the accuracy appraisal question, "always" or "nearly always" read the general types of articles.

Approximately $96 \%$ of those respondents who appraise accuracy as "very" or "fairly accurately," read Oregon Wildlife "always" or "nearly always." Only $3 \%$ of respondents feel that the magazine is "not very accurate," or "not accurate at all," "rarely" or "never" read the general articles.

These data suggest that although most respondents appraise accuracy as "very" or "fairly accurately," there is little correlation between responses of reading the magazine "always" and "nearly always" with responses of "rarely" or "never" reading the magazine. 
TABLE XIV

GENERAI ARTICLES AND ACCURACY APPRAISAL

\begin{tabular}{|c|c|c|c|c|c|c|c|c|c|c|}
\hline \multirow{2}{*}{$\begin{array}{l}\text { Accuracy } \\
\text { Appraisal }\end{array}$} & \multicolumn{2}{|c|}{ Always } & \multicolumn{2}{|c|}{$\begin{array}{l}\text { Nearly } \\
\text { Always }\end{array}$} & \multicolumn{2}{|c|}{ Rarely } & \multicolumn{2}{|c|}{ Never } & \multicolumn{2}{|c|}{$\begin{array}{c}\text { No } \\
\text { Answier }\end{array}$} \\
\hline & No. & $\%$ & No. & $\%$ & No. & $\%$ & No. & $\%$ & No. & $\%^{2}$ \\
\hline $\begin{array}{l}\text { Very } \\
\text { Accurately }\end{array}$ & 550 & 41 & 263 & 37 & 86 & 29 & 27 & 49 & 3,7 & 37 \\
\hline $\begin{array}{l}\text { Fairly } \\
\text { Accurately }\end{array}$ & 699 & 53 & 409 & 58 & 193 & 64 & 27 & 49 & 58 & 57 \\
\hline $\begin{array}{l}\text { Not Very } \\
\text { Accurately }\end{array}$ & 19 & 1 & 13 & 2 & 12 & 4 & 1 & 2 & 0 & 0 \\
\hline $\begin{array}{l}\text { Not } \\
\text { Accurately } \\
\text { at All }\end{array}$ & 13 & 1 & 3 & 0 & 2 & 1 & 0 & 0 & 0 & 0 \\
\hline No Answer & 48 & 4 & 21 & 7 & 6 & 2 & 0 & 0 & 6 & 6 \\
\hline Total & 1329 & & 709 & & 299 & & 55 & & 101 & \\
\hline
\end{tabular}

a Total percentage does not always equal 100 due to rounding of numbers. 


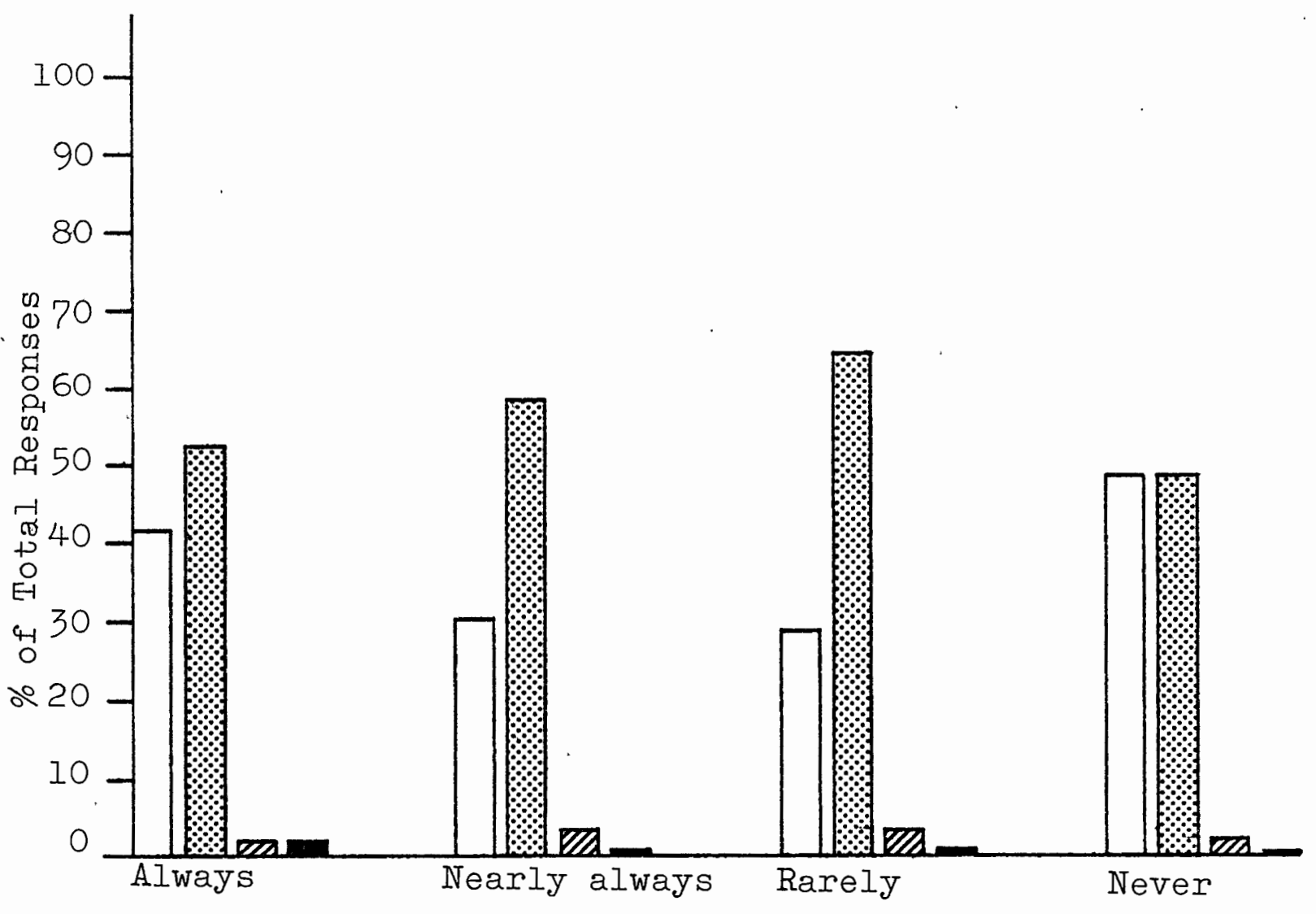

$\square$ Very accurately Not very accurately

Fairly accurately Not accurately at all

Figure 4. Histogram comparing general types of articles read and accuracy appraisal. 
Readability Appraisal and

General Articles

Table XV and Figure 5 suggest that the general types of articles are most often read "always" or "nearly always." Figure 5 also suggests that of those who "always" or "nearly always" read the articles, $80 \%$, or most respondents appraise the readability of Oregon Wildlife as "about right."

Among respondents who "rarely" or "never" read the general types of articles, $23 \%$, or most respondents feel the magazine's readability is too complex.

These data further represent Klapper's theory on the audience image of the source. Klapper suggests that the audience conception of the source influences the persuasiveness of the communication itself. Klapper expounds:

Sources, or more precisely, the audience image of the sources, affects the audience interpretation of the communication and its persuasive effectiveness. Sources regarded as credible, trustworthy, or high in prestige apparently abet persuasion; while sources inspiring more negative images apparently hinder persuasion. 4

Table XVI and Figure 6 designate that the majority of respondents consider the readability of the magazine to be "about right," regardless of whether they read the articles "always," "nearly always," "rarely," or "never." 


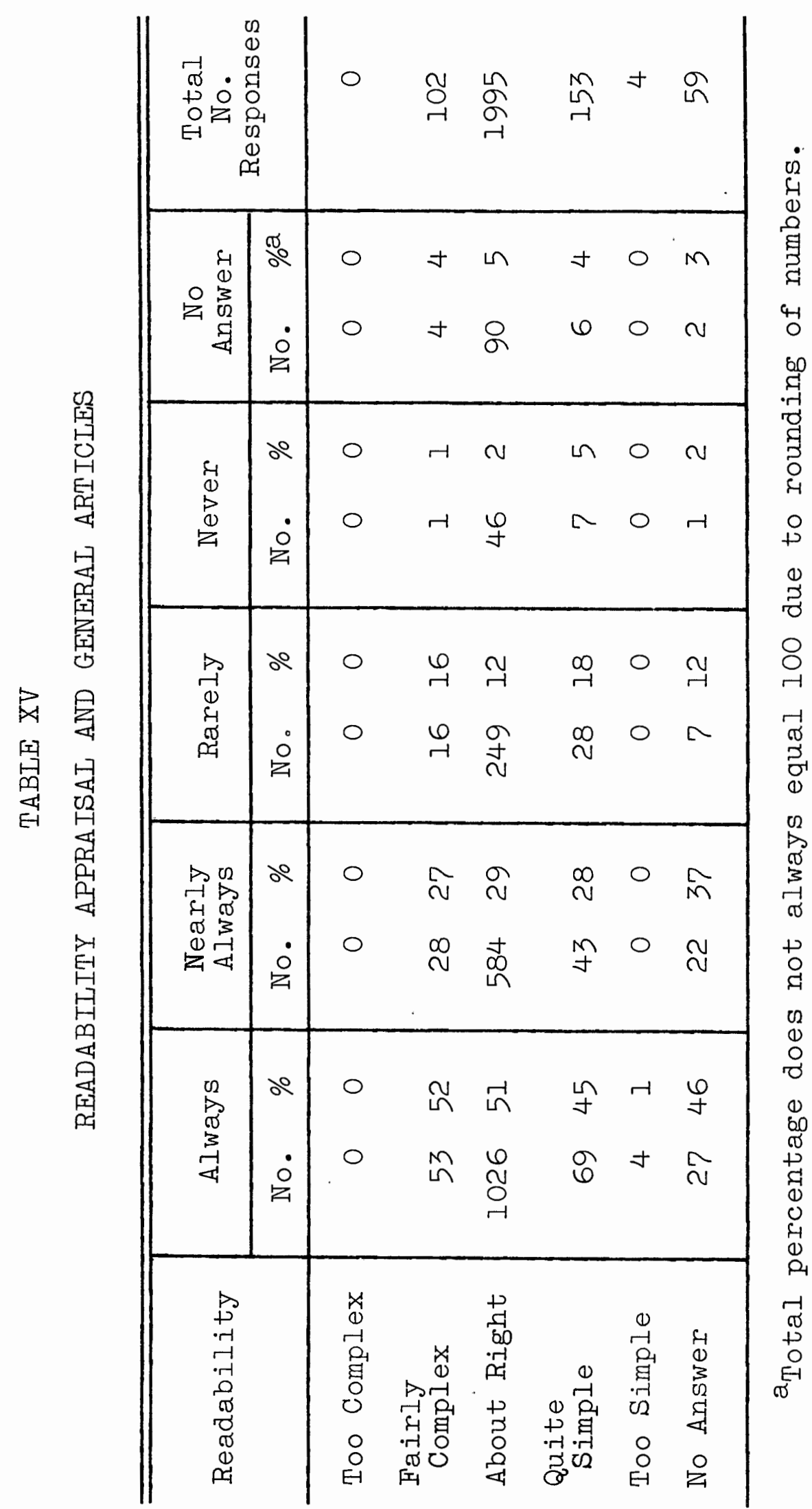




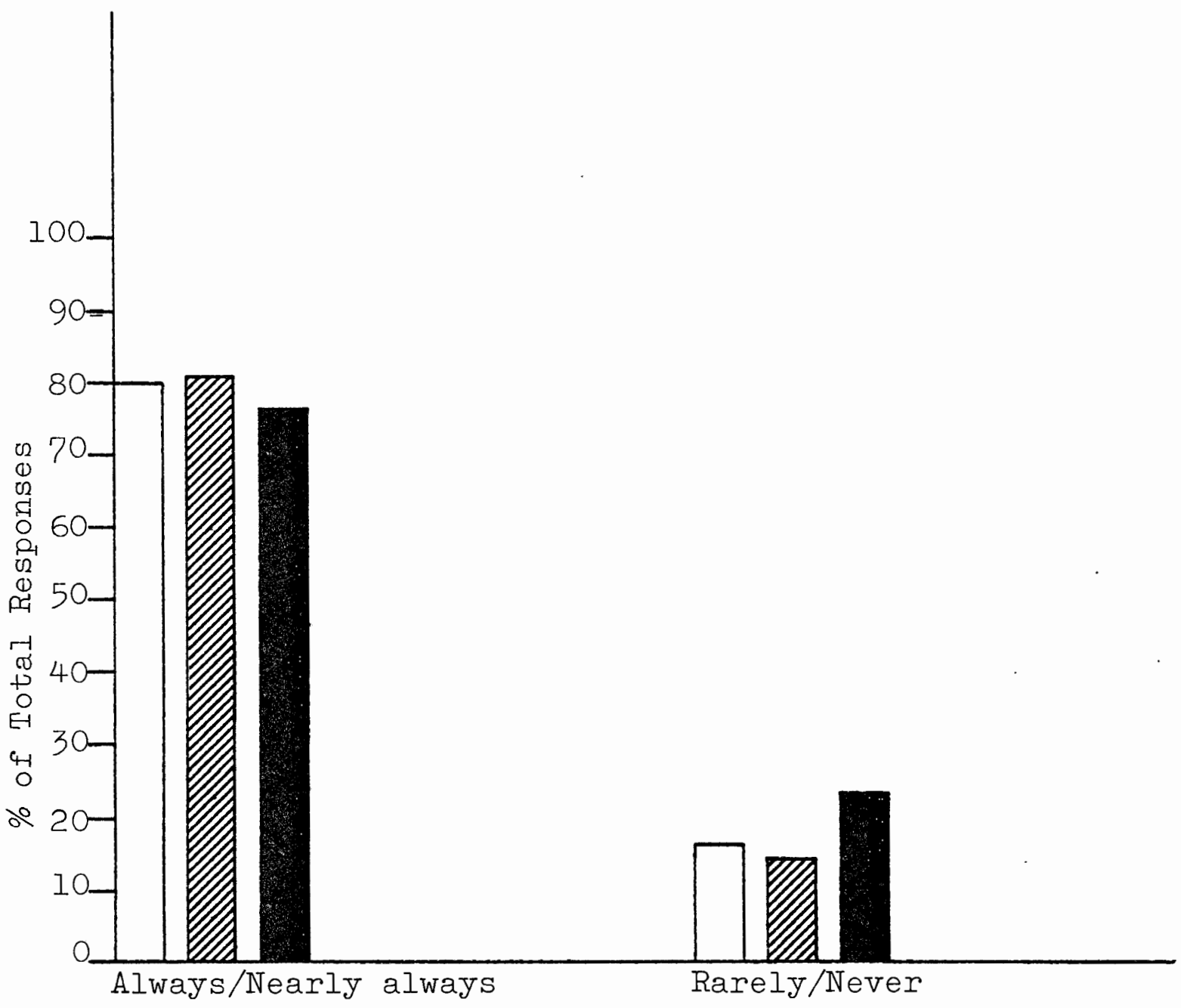

Too complex/ fairly complex
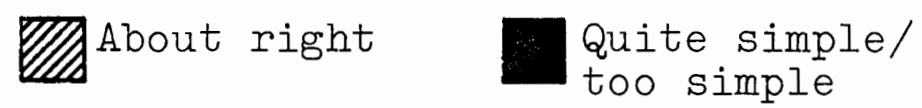

Figure 5. Histogram comparing readability appraisal and general types of articles read. 
TABLE XVI

GENERAL ARTICLES AND READABILITY APPRAISAL

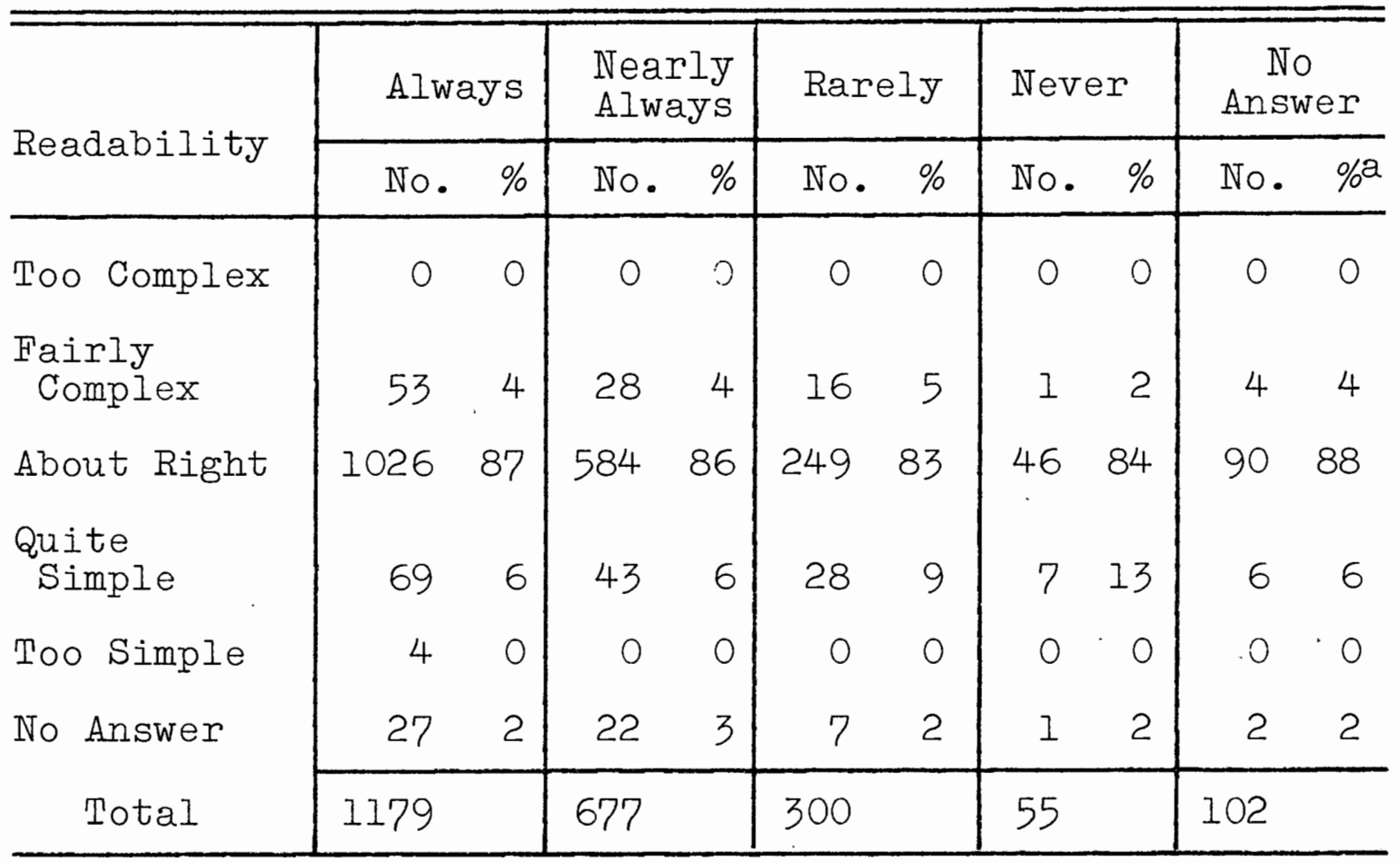

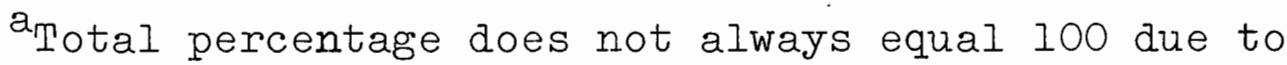
rounding of numbers. 


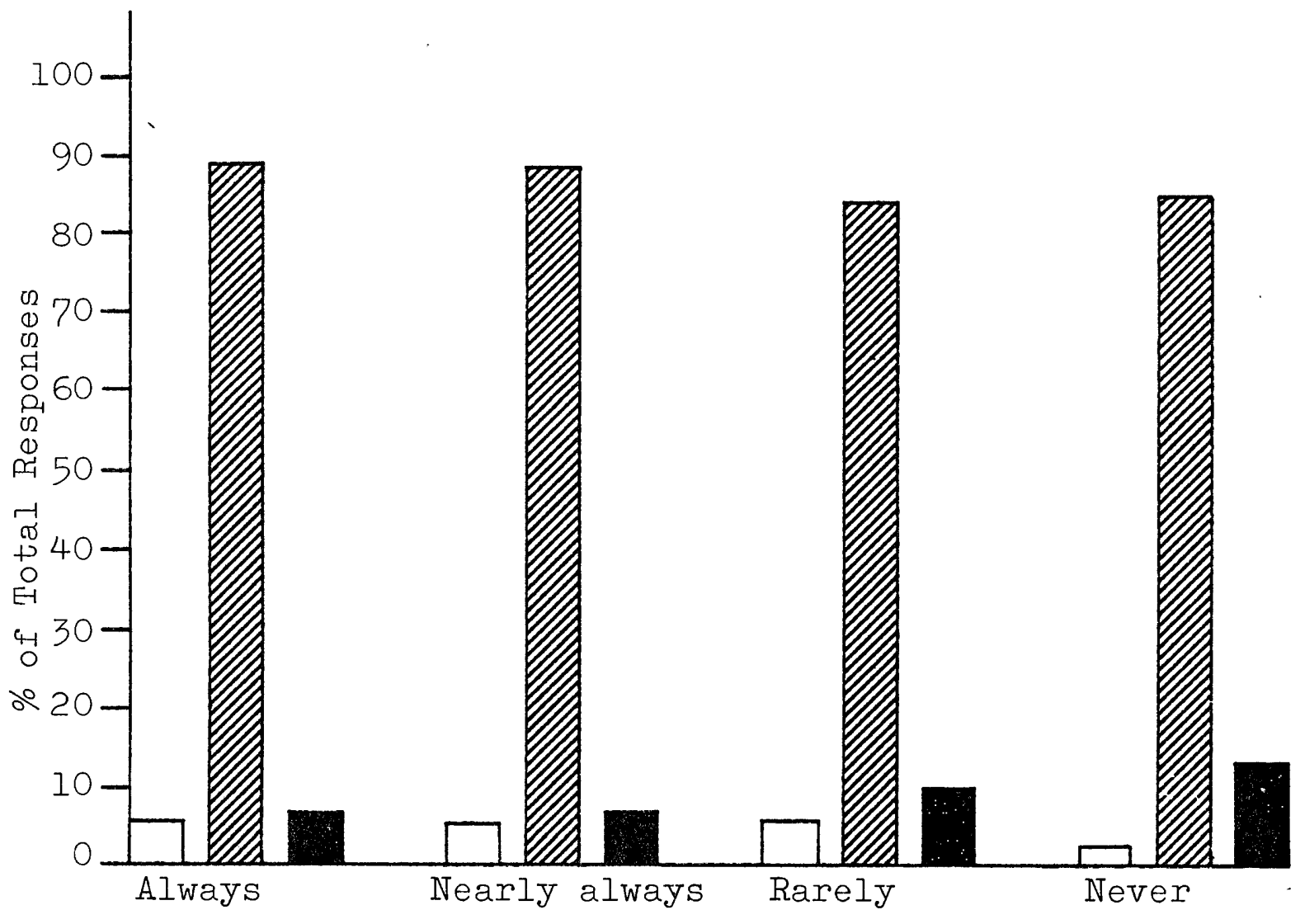

$\square$ Too complex/ $\begin{aligned} & \text { Qubout right simple/ } \\ & \text { toirly complex simple }\end{aligned}$

Figure 6. Histogram comparing general types of articles read and readability appraisal. 
Chapter 4--Notes

${ }^{1}$ Charles L. Bigelow, "Some Suggested Refinements in Newspaper Readership Studies," Journalism Quarterly, 25 (Dec., 1948), p. 349-353.

$2_{\text {U.S. Government Printing Office, Dictionary of }}$ Occupational Titles, 3rd ed., vol. 2: Occupational Classification (Washington, D.C.: 1965).

3 Joseph T. Klapper, The Effects of Mass Communication (Glencoe, Illinois: 'University of Illinois Press, 1975), p. 107.

$$
{ }^{4} \text { Ibia., p. } 129 .
$$




\section{CHAPTER V \\ SUMMARY AND CONCLUSION}

\section{SUMIMARY}

The specific question which this study was designed to investigate was: What population of individuals in Oregon read which types of fish and wildlife articles in the Oregon Wildlife magazine, and how do these respondents assess the readability and accuracy of the magazine.

The study was based on the assumption that individuals expose themselves to media which are in accord with their existing attitudes and interests, and therefore the media reinforces existing attitudes.

Few valid readership studies have been performed in the field of fish and wildlife in an attempt to learn more about its particular audience and determine the impact of the magazine media on the audience. Although data are inconclusive in answering the question of impact; it does show how subjects obtain initial exposure to the magazine as well as to what type of audience Oregon Wildlife appeals.

Results of this study indicate that a considerably greater amount of Oregon Wildlife readers are males, 
living in rural areas of Oregon. The majority of respondents are either retjred or working in labor and trade fields. More than one-half of the respondents indicated hearing about Oregon Wildlife from a "friend," as opposed to the other categories of exposure including: "store," "meeting," "work," "radio," "teacher," and "other." These other categories were all indicated by less than $14 \%$ of the respondents.

The majority of readers of Oregon Wildlife read each issue, as well as "always" or "nearly always" reading the general types of articles appearing in the magazine. Of the nine categories of general types of articles, more than $80 \%$ of respondents "always" or "nearly always" read seven of the article types. Although the articles on Monthly Meeting Information and Suggested Books are not as popular as the remaining seven categories, Monthly Meeting Information is read "always" or "nearly always" by $63 \%$ of the respondents and Suggested Books by $44 \%$ of the respondents.

The seven specific articles appearing in April's issue were "all" or "part" read by 78\% of the respondents, and the eleven specific articles in May's issue were "all" or "part" read by $76 \%$.

The following hypothesis was tested on the general types of articles since the general articles were representative of the specific articles: 
Hypothesis: There will be no significant difference between reinforcement of how often general types of articles are read as compared to the sentiments on readability and accuracy of the magazine.

The null hypothesis was rejected. The majority of respondents, or 90\% appraise the accuracy of Oregon Wildiffe as "very accurate" or "fairly accurate," and the readability as "about right." In this category, such a result could be anticipated based on the reinforcement assumption. Furthermore, as demonstrated in Figure 6 (p. 61), respondents most, often appraise readability as "about right," regardless of whether the articles are "always," "nearly always, " "rarely," or "never" read. These data appear to signify that Oregon Wildlife is considered a highly credible and trustworthy source among its readers.

Accuracy evaluation further supports Oregon Wildlife's credibility. As with readability appraisal, regardless of whether the respondent "always," "nearly always," "rarely," or "never" read the general types of articles, readers most often appraise the magazine as "very" or "fairly accurate." 
CONCLUSIONS

The results of this study have produced information of value to media communicators. The study confirmed the conclusion of some researchers that people tend to seek material from the mass media which is compatible with their preexisting views. This conclusion was based on the finding that the majority of respondents evaluated the accuracy of Oregon Wildlife as "very" or "fairly accurate," and the readership as "about right."

Although the majority of respondents were first exposed to Oregon Wildlife from a friend, proportionately, those who first heard about the magazine on the radio appear to be avid readers.

It was most often noted by subscribers that general articles are "always" or "nearly always" read. Similar to general article readership, specific articles in April and May issues were also most often all or partially read.

The sample indicated that respondents consider Oregon Wildlife to be a credible and trustworthy source. Regardless of whether subscribers "always" or "never" read the articles, the majority of subscribers interpretation of the magazine is that of an accurate and agreeable source.

Since Oregon Wildlife is a specialized source, it appears to be highly persuasive for its own specialized audience. 
SUGGESTIONS FOR FURTHER RESEARCH

It appears from this study that further studies are necessary to improve and elaborate on the theories and evaluations drawn on this sample.

1. What is the relationship between number of persons reached by media and personal influence? It would be useful to know whether those reached by the media are more objective evaluators of the source. It appears that the personal influence together with the media source is more persuasive, yet the extent of seriousness of attitude which the individual holds still is in question.

2. Investigation of why Suggested Books and Monthly Meeting Information articles are not read to the extent of the other articles. Gilbert explains that managers of natural resources should keep their knowledge level of their public at the same level or at a higher level as that of the management. It appears that the public are not at the same specialized level as the management. Further study should suggest ways in which publications can be restructured to facilitate reader interest in the Monthly Meeting Information and Suggested Books. 


\section{A SELECTED BIBLIOGRAPHY}

American Institute for Political Communication. Evolution of Public Attitudes Toward the Mass Media During an Election Year. Washington, D.C.: November 1969.

- The Effects of Local Media Monopoly on the Mass Mind. Washington, D.C.: January 1971.

Bauer, Raymond A. "The Communicator and the Audience," Journal of Conflict Resolution, 2, No. I (March, 1958), 67-77.

Bigelow, Charles L. "The Absolute Measurement of Reader Interest," Journalism Quarterly, 23, No. 3 (Sept., 1971), 280-287.

Brinton, James E. "Subscriber vs. Non-Subscriber Method for Studying Effects," Journalism Quarterly, 34 (Winter, 1957), 475-480.

Blumer, Jay G., and Katz, Elihu. The Uses of Mass Communications. Beverly Hills/London: Sage Publications, 1974.

Cochran, William G. Sampling Techniques. New York: John Wiley and Sons, 1953.

Davison, W. Phillips. "On the Effects of Communication," Public Opinion Quarterly, (1.960), 344-360.

DeFleur, David I., and Ball-Rokeach, Sandra. Theories of Mass Communication. 3rd ed. New York: David McKay Co., 1975.

Dexter, Lewis A., and White, David M. People, Society and Mass Communications. London: Collier-MacMillan Itd., 1964 .

Fitzgerald, Stephen E. Communicating Ideas to the Public. New York: Funk and Wagnalls Co., 1950.

Hennessy, Bernard C. Public Opinion. Belmont, California: Wadsworth Publishing Co., Inc., 1970. 
Katz, Daniel. "The Art of Asking Why: Three Principles Underlying the Formulation of Questionnaires." New York: Dryden Press, 1954, pp. 675-686, reprinted from National Marketing Review, 1 (1935), 32-43.

Kearl, Bryant. "The Non-Reader in a Magazine Readership Survey," Journalism Quarterly, 34 (Fal1, 1957), 475480 .

Klapper, Joseph T. The Effects of Mass Communication. Glencoe, Illinois: The Free Press, 1960.

Lazarsfeld, Paul F., Berelson, Bernard, and Gaudet, Helen. The People's Choice. New York: Duell, Sloan, and Pearce, 1944.

, and Kendall, Patricia. "The Communication

Behavior of the Average American," in Mass Communicants, pp. 425-437. Edited by Wilbur Schramm. Urbana, Illinois: University of Illinois Press, 1960.

, and Wyant, Rowena. "Magazines in 90 Cities Who Reads What?" Public Opinion Quarterly, 1 (October, 1937), 35-36.

MacCannell, Earle H. "Mass Communication." Study guide for upper division Sociology. Portland State University, Sociology department, September, 1977.

McIuhan, Marshall. Understanding Media. New York: Signet Books, 1964.

Merrill, John C., and Lowenstein, Ralph I. Media, Messages, and Men. New York: David McKay Company, Inc., 1971.

Moeller, G., and Budd, Richard W. "Readership of and Attitudes Toward Journalism Quarterly," Journalism Quarterly, 39 (1962), 471-482, 552.

Moznette, James, and Rarick, Galen. "Research in Brief," Journalism Quarterly, 45 (Summer, 1968), 319-338.

O'Hara, Robert C. Media for the Millions. New York: Random House, 1962 .

Peterson, Theodore. Magazines in the Twentieth Century. 2nd ed. Urbana, Illinois: University of Illinois Press, 1975. 
Pierson, Thomas A., Beattie, Kirk, and Gillam, Harry. "Results of the Virginia Wildlife Readership Preference Survey, "Virginia Wildlife, 39, No. I (Feb., 1978), 10-12, 21 .

Sandman, Peter M., Rubin, David B., and Sachsman, David B. Media: An Introductory Analysis of American Mass Communication. Englewood Cliffs, New Jersey: Prentice-Hall Inc., 1972.

Schramm, Wilbur, and White, David M. "Age Education, Economic Status: Factors in Newspaper Reading," Journalism Quarterly, 26, No. 2 (June, 1949), 149-159.

Shay, Ronald E. "A Comparison Between Sources of Student Anti-Hunting Sentiment and Wildlife Information Sources of a Sample of Oregon Adults." M.s. thesis, Portland State University, 1974.

Snedecor, George W. Statistical Methods. Ames, Iowa: The Iowa State Press, 1965.

U.S. Government Printing Office. Dictionary of Occupational Titles. 3rd ed. Vol. 2: Occupational Classification. Washington, D.C.: 1965.

Wallinger, Ruth A. "Western Speech: Readership and Reaction," Western Journal of Speech Communication, No. 1 (Winter, 1972), 53-62.

"What Criteria Should Be Used to Judge the Admissibility of Evidence to Support Theoretical Propositions in Communication Research?" Journal of Speech Communication, 41, No. 1 (Winter, 1977), $1-65$. 
APPENDIX A

COVER LETTER AND QUESTIONNAIRE 
COVER IETTER AND QUESTIONNAIRE

April 22, 1977

Dear Oregon Wildlife Subscriber:

In the following questionnaire, we are interested in your evaluation of Oregon Wildlife magazine. We would like to know what parts of the magazine are of greatest and least interest to you so that we will be able to make oregon Wildlife more useful to all readers. We would appreciate your help in taking a few minutes to complete the questionnaire and return it in the enclosed stamped envelope.

You are part of a very SMALI SAMPLE GROUP, so each of your answers is extremely important. Your individual responses will be kept ABSOLUTELY CONFIDENTIAI.

Thank you so much for your assistance. We hope that, with the results of this questionnaire, we will be able to serve you even better in the future.

Sincerely,

Ron E. Shay, Editor

OREGON WIIDLIFE

Enclosures 
OREGON WILDLIFE Readership Survey

$A G E$ SEX OCCUPATION

TOWN OR CITY IN WHICH YOU IIVE

I LIVE IN :
A metropolitan area
A city of 10,000 to $\overline{50,000}$
A rural area

FOR NUMBERS I THROUGH 4, PLEASE CIRCLE ONE RESPONSE OR WRITE IN YOUR ANSWER AFTER "OTHER."

I. How did you hear about Oregon Wildlife? friend, radio, at a meeting, saw at a store, other

2. Do you read each issue? yes no

3. How many people other than yourself read YOUR copy? $1,2,3,4,5,6$ more

4. How many years have you been reading Oregon Wildlife? $1 / 2,1,2,3,4,5$ more If more than 5 years, how many more?

BELOW ARE IISTED THE DIFFERENT KINDS OF ARTICLES THAT APPEAR IN ISSUES OF OREGON WILDLIFE. PLEASE INDICATE HOW OFTEN YOU READ EACH KIND OF ARTICLE, WHEN IT DOES APPEAR, BY CIRCLING ONE RESPONSE ON EACH IINE.

MONTHLY MEETING

INFORMATION

"THIS AND THAT"

WILDLIFE

EDUCATION

WIIDLIFE FEATURE STORIES

FISH FEATURE STORIES

FISH AND WILDLIFE REGULATIONS
Always Nearly always Rarely Never

Always Nearly always Rarely Never

Always Nearly always Rarely Never

Always Nearly always Rarely Never

Always Nearly always Rarely Never

Always Nearly always Rarely Never 
MANAGEMENT

INFORMAT ION

SUGGESTED BOOKS

EDITORIALS
Always Nearly always Rarely Never

Always Nearly always Rarely Never

Always Nearly always Rarely Never

BELOW ARE IISTED THE' SPECIFIC ARTICLES WHICH APPEARED IN THE APRII 1977 ISSUE OF OREGON WIIDLIFE. PLEASE INDICATE HOW MUCH OF EACH ARTICLE YOU READ BY CIRCLING ONE RESPONSE ON EACH IINE.

"THE BIG DUMPING

GROUNDS IN THE

SEA" (Editorial) All Part Title Don't remember None

"COMMISS ION

MEET INGS

All Part Title Don't remember None

" '200 MILE ZONE-

RCMA-REGIONAL

COUNC IIS-RCZ'

WHAT DO THESE

TERMS MEAN TO

OREGON IANS?

"SANDY SMELT"

"BIRDS IN THE

BUSH - AND

ELSEWHERE"

All Part Title Don't remember None

All Part Title Don't remember None

"SAUVIE ISLAND

CHRISTMAS BIRD

COUNT DECEMBER

19, 1976" (List) All Part Title Don't remember None

"NEW REGULATIONS

GOVERN BAY CIAM

DIGG ING"

All Part Title Don't remember None

All Part Title Don't remember None

FOR NUMBERS I THROUGH 4, PLEASE CIRCLE ONE RESPONSE OR WRITE IN YOUR ANSWER.

1. How accurately do' you feel Oregon Wildlife describes and represents what's going on in the field throughout the state?

very accurately, fairly accurately, not very accurately, not accurately at all 
2. How would you appraise the overall readability (style of writing) of the articles currently appearing in oregon Wildiife?

too complex, fairly complex, about right, quite simple too simple

3. Do you subscribe to any other hunting, fishing, or wildlife oriented magazines?

yes no If you circled "yes," please indicate which one $(s)$.

4. Have you purchased a hunting or angling license within the past 5 years? yes no

Thank you so much for your time and effort. If you feel that any of your answers need more explanation or you wish to comment further about Oregon Wildlife, please feel free to elaborate in the space below. 
OREGON WILDLIFE Readership Survey

$\Lambda(i l i$ is OCCIUPATION

TOWN OR CITY TN WHICH YOU LIVE

I LIVE IN :
A metropolitan area
A city of 10,000 to 50,000
A rural area

FOR NUMBERS I THROUGH 4, PLEASE CIRCLE ONE RESPONSE OR WRITE IN YOUR ANSWER AFTER "OTHER."

1. How did you hear about Oregon Wildlife? friend, radio, at a meeting, saw at a store, other

2. Do you read each issue? yes no

3. How many people other than yourself read YOUR copy? $1,2,3,4,5,6$ more

4. How many years have you been reading Oregon Wildlife? $1 / 2,1,2,3,4,5$ more If more than 5 years, how many more?

BELOW ARE LISTED THE DIFFERENT KINDS OF ARTICLES THAT APPEAR IN ISSUES OF OREGON WILDLIFE. PLEASE INDICATE HOW OFTEN YOU READ EACH KIND OF ARTICLE, WHEN IT DOES APPEAR, BY CIRCLING ONE RESPONSE ON EACH LINE.

MONTHLY MEETTNG

INFORMAT ION

"THIS AND THAT"

WIIDLIFE

EDUCATION

WILDLIFE FEATURE

STORIES

FISH FEATURE

STORIES

FISH AND WILDLIFE

REGULAT IONS
Always Nearly always Rarely Never

Always Nearly always Rarely Never

Always Nearly always Rarely Never

Always Nearly always Rarely Never

Always Nearly always Rarely Never

Always Nearly always Rarely Never 
MANAGEMENT

INFORMAT ION

SUGGESTED BOOKS

EDITORIALS
Always Nearly always Rarely Never

Always Nearly always Rarely Never

Always Nearly always Rarely Never

BELOW ARE LISTED THE SPECIFIC AFTICLES WHICH APPEARED IN THE MAY 1977 ISSUE OF OREGON WILDLIFE. PLEASE INDICATE HOW MUCH OF EACH ARTICLE YOU READ BY CIRCLING ONE RESPONSE ON EACH LINE.

"LET THE PUNISHMENT

FIT THE CRIME"

(Editorial)

All Part Title Don't remember None

"COMMISSION

MEET INGS"

"1976 BIG GAME

HUNT ING SEASONS"

"1976 DEER

SEASON" (List)

"1976 ELK

SEASON" (List)

"DEER HUNTING

TRENDS 1952-1976" (List)

All Part Title Don't remember None

All Part Title Don't remember None

All Part Title Don't remember None

All Part Title Don't remember None

"ELK HUNTING

TRENDS 1933-1976"

(List)

All Part Title Don't remember None

"1976 ANTELOPE SEASON (74\% REPORT

CARD RETURN)"

(List)

All Part Title Don't remember None

"PISCATORIAL

PARENTHOOD OF THE LINGCOD"

All Part Title Don't remember None

"TEST FISHING"

"LOCAL TOWN HALI MEETINGS"

All Part Title Don't remember None

All Part Title Don't remember None

All Part Title Don't remember None

FOR NUMBERS 1 THROUGH 4, PLEASE CIRCLE ONE RESPONSE OR WRITE IN YOUR ANSWER.

1. How accurately do you feel Oregon Wildlife describes and 
represents what's going on in the field throughout the stite?

very accurately, fairly accurately, not very accurately, not accurately at all

2. How would you appraise the overall readability (style of writing) of the articles currently appearing in Oregon Wildlife?

too complex, fairly complex, about right, quite simple too simple

3. Do you subscribe to any other hunting, fishing, or wildlife oriented magazines?

yes no If you circled "yes," please indicate which one $(\mathrm{s})$.

4. Have you purchased a hunting or angling license within the past 5 years? yes no

Thank you so much for your time and effort. If you feel that any of your answers need more explanation or you wish to comment further about Oregon Wildlife, please feel free to elaborate in the space below. 


\section{APPENDIX B}

COMPARISON OF INDEPENDENT VARIABLES AND RESPONSES TO GENERAI TYPES OF ARTICLES READ

(AGE, OCCUPATION, LOCALITY) 


\section{TABLE XVII}

CONPARTSON OF AGE AND RESPONSES TO

GENERAL TYYPES OF ARTICLES READ

\begin{tabular}{c|ccccc}
\hline Age & Always & $\begin{array}{c}\text { Nearly } \\
\text { Always }\end{array}$ & Rarely & $\begin{array}{c}\text { Never } \\
\text { Alwo }\end{array}$ & $\begin{array}{c}\text { No } \\
\text { Answer }\end{array}$ \\
\hline $10-19$ & 23 & 19 & 12 & 2 & 3 \\
$20-29$ & 73 & 45 & 33 & 9 & 2 \\
$30-39$ & 150 & 101 & 49 & 7 & 3 \\
$40-49$ & 190 & 74 & 36 & 6 & 3 \\
$50-59$ & 255 & 127 & 65 & 12 & 12 \\
$60-69$ & 367 & 131 & 65 & 15 & 23 \\
$70-79$ & 208 & 60 & 26 & 4 & 16 \\
$80-89$ & 57 & 23 & 7 & 0 & 9 \\
\hline \multirow{2}{*}{ Total } & 1323 & 580 & 293 & 55 & 71 \\
\hline
\end{tabular}


TABLE XVIII

COMPARISON OF OCCUPATIONS AND RESPONSES TO

GENERAL TYPES OF ARTICLES READ

\begin{tabular}{l|rrrrr}
\hline Occupations & Always & $\begin{array}{c}\text { Nearly } \\
\text { Always }\end{array}$ & Rarely & $\begin{array}{c}\text { Never } \\
\text { Answer }\end{array}$ \\
\hline Professional & 150 & 137 & 62 & 10 & 3 \\
Labor/trade & 509 & 226 & 107 & 25 & 4 \\
Public & & & & & \\
Service & 81 & 45 & 16 & 1 & 16 \\
Sales & 32 & 14 & 16 & 1 & 1 \\
Student & 13 & 11 & 8 & 2 & 0 \\
Research & 6 & 11 & 9 & 1 & 2 \\
Retired & 546 & 214 & 79 & 13 & 39 \\
Not & & & 2 & 2 & 6 \\
employed & 52 & 10 & 2 & 0 & 28 \\
No answer & 7 & 876 & 301 & 55 & 99 \\
\hline
\end{tabular}


TABLE XIX

COMPARISON OF LOCALITY AND RESPONSES TO GENERAL TYPES OF ARTICLES READ

\begin{tabular}{l|ccccc}
\hline \hline Locality & Always & $\begin{array}{c}\text { Nearly } \\
\text { Always }\end{array}$ & Rarely & Never & $\begin{array}{c}\text { No } \\
\text { Answer }\end{array}$ \\
\hline Metro area & 267 & 173 & 74 & 19 & 15 \\
$\begin{array}{l}\text { City 10,000- } \\
50,000\end{array}$ & 267 & 116 & 69 & 5 & 21 \\
Rural area & 787 & 364 & 164 & 31 & 38 \\
No answer & 0 & 5 & 4 & 0 & 27 \\
\cline { 2 - 5 } Total & 1315 & 658 & 311 & 55 & 101 \\
\hline
\end{tabular}

